\title{
Alaska's Mineral Industry 2005: A SUMMARY
}

D.J. Szumigala and R.A. Hughes

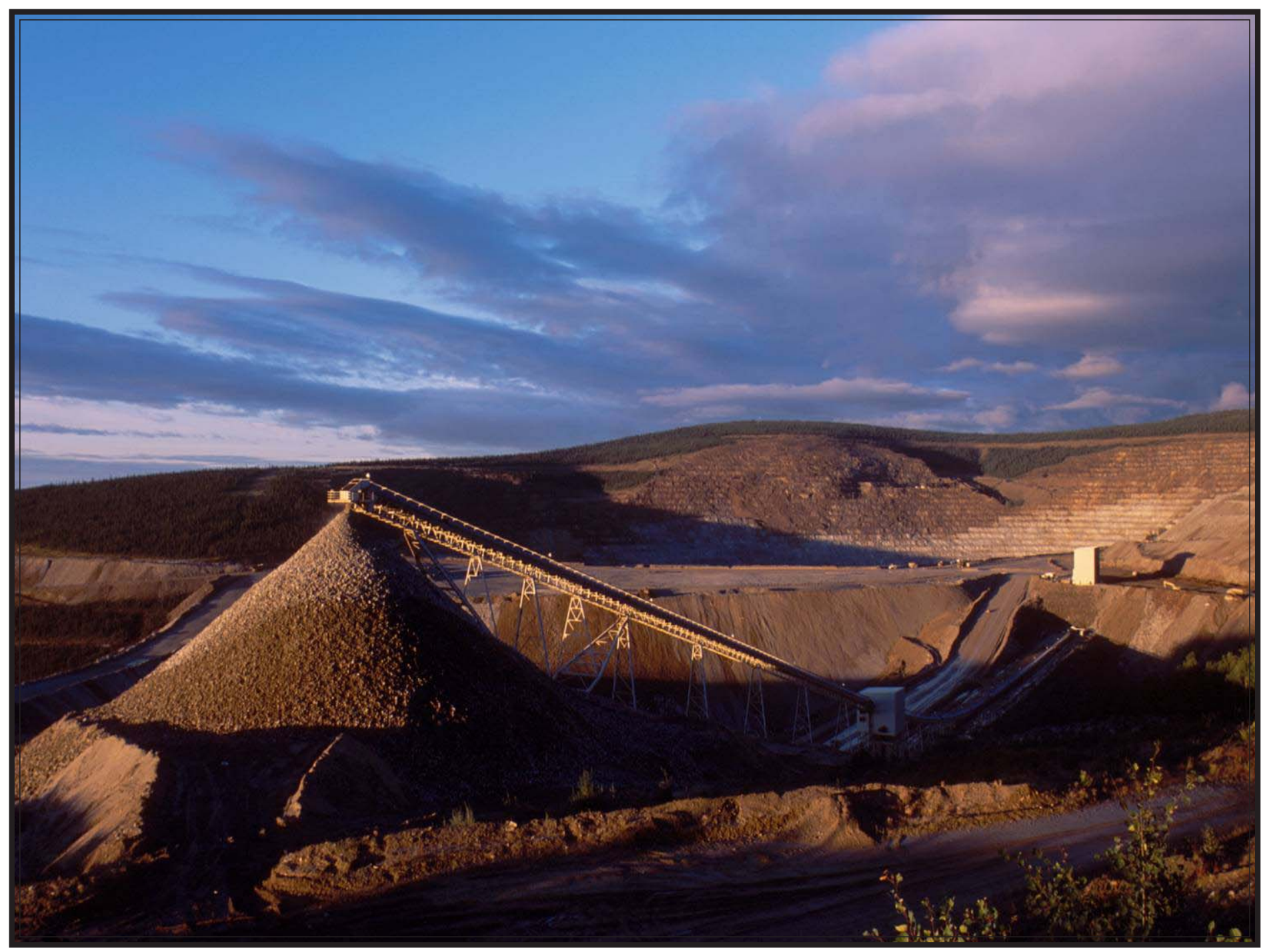

Overview of Fort Knox Mine looking south by southeast. The open pit gold mine is seen in the background, with the low-grade ore stockpile and conveyor in the foreground. The Fort Knox Mine near Fairbanks produced 329,320 ounces of gold in 2005 and mined 13.23 million tons of ore and 5.86 million tons of low-grade ore to stockpile. Photo provided by Fairbanks Gold Mining Co. 


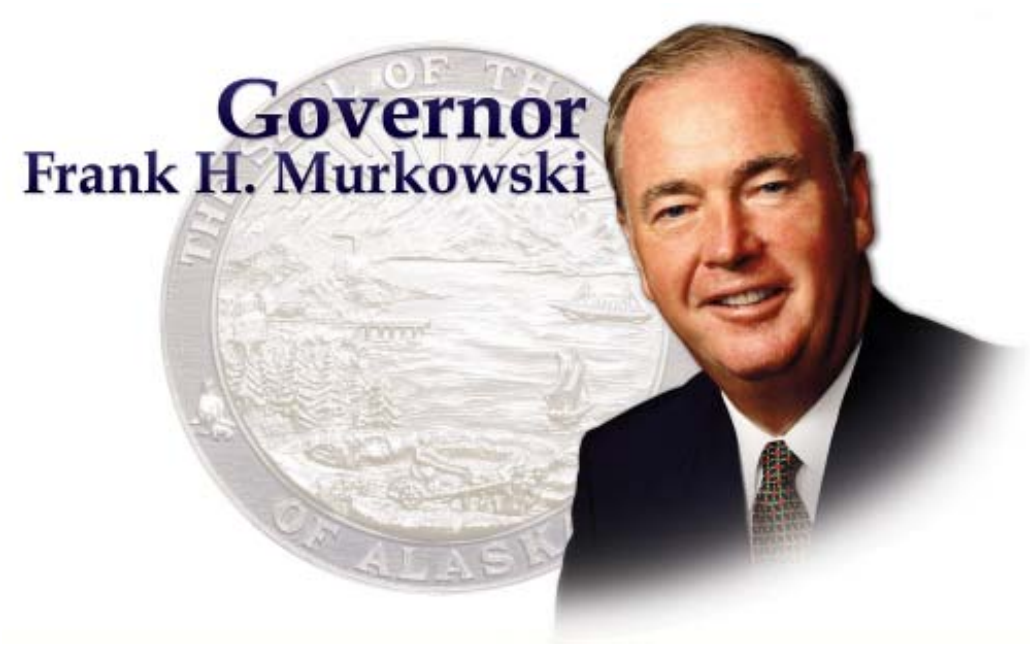

It is a pleasure to report the continuing strength in Alaska's mining industry in 2005. Development of our mineral resources generates wealth for our state, offers good job opportunities for Alaskans, and operates in well-regulated balance with our natural environment.

This preliminary assessment of the industry shows its total value rose to $\$ 1.8$ billion in 2005, a new record. That total includes $\$ 1.36$ billion worth of minerals production, $\$ 347.1$ million in development, and \$100.9 million for statewide exploration. Continued investment in Alaska's mines and exploration for additional mines bodes well for continued expansion of our mineral industry.

Mining provided more than 2,170 full-time equivalent jobs in Alaska. With five operating mines, and a number of promising prospects under exploration and development, the prospects for continued health in the industry look even brighter for the future.

It is an exciting time to be involved in Alaska's resurgent minerals industry. The information contained in this report offers solid evidence that mining remains a vital part of our state and economy, and will continue to provide significant benefits to Alaskans.

Frank H. Murkowski

Governor 


\title{
Alaska's Mineral Industry 2005: A Summary
}

\author{
by \\ D.J. Szumigala ${ }^{1}$ and R.A. Hughes ${ }^{2}$
}

\section{INTRODUCTION}

Alaska's mineral industry had a very strong year in 2005, propelled by strong metal prices and renewed interest in Alaska's outstanding mineral endowment. Total value of Alaska's mineral industry will exceed $\$ 1.8$ billion in 2005, a record value and the tenth consecutive year above $\$ 1$ billion. Table 1 shows the estimated annual value of the mineral industry in Alaska between 1981 and 2005, as divided between exploration and development investments, and the gross value of the mineral products. These preliminary combined values total $\$ 1.81$ billion in 2005, compared to \$1.62 billion in 2004.

This summary of Alaska's mineral industry activity for 2005 is made possible by information provided through press releases, annual reports, phone interviews, and replies to questionnaires mailed by the Alaska Division of Geological \& Geophysical Surveys (DGGS). The final report will be available later in the year after further compilation of information, particularly for placer mining and industrial minerals. This report is part of a cooperative venture between DGGS and the Division of Mining, Land \& Water (DMLW) in the Department of Natural Resources (DNR) and the Office of Economic Development, Department of Commerce, Community and Economic Development (Commerce). The estimates used in this summary are generally conservative because data have not yet been completely reported. This summary and data contained within it will be superceded by DGGS Special Report 60 to be published later in 2006.

Exploration expenditures rose significantly above robust 2004 levels to over \$100 million. At least 16 projects had exploration expenditures of $\$ 1$ million or more and these projects spanned Alaska. Development investment increased to exceed \$347 million in 2005, 166 percent over the 2004 mineral investment value. Mine construction continued at Teck Cominco Inc.Sumitomo Metal Mining Co.'s Pogo gold project in eastern Alaska and construction began at Coeur Alaska Inc.'s Kensington gold project in southeastern Alaska.

Production volumes from Alaska's lode mines were down compared to 2004, with the exception of zinc production. However, metal price improvements overcame production shortfalls. Production values amounted to
\$1.357 billion, a slight increase from 2004's value of \$1.339 billion. The Pogo Mine is expected to begin gold production in the first half of 2006, the Nixon Fork Mine has projected gold production by late 2006, and the Kensington Mine has planned gold production by mid 2007. At the time of this publication, information from the rock, sand, and gravel industry was incomplete, resulting in lower preliminary values for 2005.

Table 1. Total value of the mineral industry in Alaska by year (in millions of dollars U.S.)

\begin{tabular}{|c|c|c|c|c|}
\hline & $\begin{array}{c}\text { Exploration } \\
\text { (expenditure) }\end{array}$ & $\begin{array}{l}\text { Development } \\
\text { (expenditure) }\end{array}$ & $\begin{array}{l}\text { Production } \\
\text { (value) }\end{array}$ & $\begin{array}{c}\text { Total } \\
\text { (calculated) }\end{array}$ \\
\hline 1981 & 76.3 & 24.7 & 188.6 & 289.6 \\
\hline 1982 & 45.6 & 41.6 & 196.4 & 283.6 \\
\hline 1983 & 34.1 & 27.9 & 212.4 & 274.4 \\
\hline 1984 & 22.3 & 53.4 & 199.4 & 275.1 \\
\hline 1985 & 9.2 & 34.1 & 226.6 & 269.9 \\
\hline 1986 & 8.9 & 24.3 & 198.5 & 231.7 \\
\hline 1987 & 15.7 & 100.3 & 202.4 & 318.4 \\
\hline 1988 & 45.5 & 275.0 & 232.2 & 552.7 \\
\hline 1989 & 47.8 & 134.3 & 277.0 & 459.1 \\
\hline 1990 & 63.3 & 14.3 & 533.0 & 610.6 \\
\hline 1991 & 39.9 & 25.6 & 546.5 & 612.0 \\
\hline 1992 & 30.2 & 29.6 & 560.8 & 620.6 \\
\hline 1993 & 30.3 & 27.7 & 448.7 & 506.7 \\
\hline 1994 & 31.1 & 45.0 & 507.5 & 583.6 \\
\hline 1995 & 34.3 & 148.6 & 537.2 & 720.1 \\
\hline 1996 & 44.7 & 394.0 & 590.4 & $1,029.1$ \\
\hline 1997 & 57.8 & 168.4 & 936.2 & $1,162.4$ \\
\hline 1998 & 57.3 & 55.4 & 921.2 & $1,033.9$ \\
\hline 1999 & 52.3 & 33.8 & $1,032.9$ & $1,119.0$ \\
\hline 2000 & 34.9 & 141.7 & $1,106.4$ & $1,283.0$ \\
\hline 2001 & 23.8 & 81.2 & 917.3 & $1,022.3$ \\
\hline 2002 & 26.5 & 34.0 & $1,012.8$ & 1,073.3 \\
\hline 2003 & 27.6 & 39.2 & $1,000.7$ & $1,067.5$ \\
\hline 2004 & 70.8 & 209.1 & $1,338.7$ & $1,618.6$ \\
\hline 2005 & 100.9 & 347.1 & $1,357.4$ & $1,805.4$ \\
\hline Total & $1,031.1$ & $2,510.3$ & $15,281.2$ & $18,822.6$ \\
\hline
\end{tabular}

Source: Alaska’s Mineral Industry reports published annually by DGGS/Commerce.

\footnotetext{
${ }^{1}$ Alaska Division of Geological \& Geophysical Surveys, 3354 College Rd., Fairbanks, Alaska 99709-3707

${ }^{2}$ Alaska Office of Mineral Development, 211 Cushman St., Fairbanks, Alaska 99701
} 


\section{EMPLOYMENT}

Table 2 lists estimated employment in the Alaska minerals industry for the past eight years. The total minerals industry employment in 2005 is estimated to be 2,170 fulltime-equivalent jobs, a decrease of 878 jobs from the estimated 2004 total of 3,048 jobs. With more complete data, especially for the sand and gravel and placer gold mining sectors, the number of 2005 jobs will likely rise, approaching the 2004 value. Most of the employment increase was in the exploration and development sectors. It is expected that the number of jobs in the development sector will decrease for 2006 because the construction phase of the Pogo project is complete. The number of jobs will increase significantly in the lode gold production sector as the Pogo Mine begins production in 2006. Higher gold prices may also spur more placer gold mining and employment.

\section{EXPLORATION}

Exploration expenditures in Alaska during 2005 were at least \$100.9 million, 42 percent higher than the $\$ 70.8$ million spent in 2004. Figure 1 shows the location of the most significant exploration projects in Alaska during 2005. Increased exploration expenditures in Alaska mirror increased worldwide mineral exploration budgets. The increases in worldwide exploration expenditures resulted from a combination of increased spending by major mining companies, a significant reduction in the negative influence of industry consolidation from peak years 2000 and 2001, and higher spending by junior mining companies in response to stronger gold and base-metal prices. The stronger Canadian dollar and attractive tax incentives for investors in Canada-based projects likely limited even more investment in Alaska.

At least 16 projects had exploration expenditures of \$1 million or more and these projects extended across Alaska. Figure 2 shows 2005 exploration expenditures in Alaska by region as described in text. More than \$58 million was spent in southwestern Alaska, with \$9.6 million spent in eastern Interior Alaska, \$9.4 million spent in southeastern Alaska and roughly \$9 million spent in western and southcentral Alaska. As in years past, most exploration funds (more than 73 percent) were derived from Canadian sources. At least 500,000 feet of core and rotary drilling were completed in 2005 on exploration projects.

Companies explored for a wide variety of mineral deposits in Alaska during 2005. Table 3 lists exploration expenditures by commodity. Gold remained a major exploration commodity, but exploration for copper-gold porphyry systems (grouped with polymetallic deposits) was the major exploration target in 2005 (table 3). Base-metal exploration expenditures decreased significantly from 2004 levels. Platinum-group-element exploration remained steady. Figure 3 shows 2005 Alaska exploration expenditures by deposit type. Almost half ( $\$ 45.8$ million) of the $\$ 100.9$ million exploration expenditures were spent on porphyry copper-gold properties. In excess of \$23.1 million was spent on intrusion-related gold deposits, with $\$ 16.3$ million spent on various gold-quartz vein deposits,

Table 2. Estimated Alaska mine employment, 1998-2005a

\begin{tabular}{|c|c|c|c|c|c|c|c|c|}
\hline & 1998 & 1999 & 2000 & 2001 & 2002 & 2003 & 2004 & 2005 \\
\hline \multicolumn{9}{|l|}{ Gold/silver mining } \\
\hline Placer & 710 & 591 & 470 & 176 & 148 & 82 & 64 & 45 \\
\hline Lode & 345 & 296 & 274 & 337 & 413 & 325 & 433 & 411 \\
\hline Polymetallic mining & 275 & 275 & 275 & 275 & 262 & 295 & 265 & 250 \\
\hline Base Metals mining & 466 & 549 & 556 & 559 & 580 & 388 & 508 & 449 \\
\hline Recreational mining & 255 & 240 & 250 & 210 & 180 & 175 & 175 & 93 \\
\hline Sand \& Gravel mining & 658 & 590 & 603 & 556 & 702 & 349 & 567 & 62 \\
\hline Rock & 121 & 128 & 150 & 137 & 177 & 35 & 475 & 24 \\
\hline Coal & 128 & 121 & 121 & 121 & 100 & 65 & 90 & 95 \\
\hline Peat $^{\mathrm{b}}$ & 40 & 38 & 36 & 32 & 21 & 20 & 4 & 6 \\
\hline $\begin{array}{l}\text { Tin, jade, soapstone, ceramics, } \\
\text { platinum mining }\end{array}$ & 20 & 20 & 20 & 20 & 20 & 20 & 0 & 0 \\
\hline Mineral development & 177 & 135 & 345 & 333 & 135 & 64 & 283 & 494 \\
\hline Mineral exploration & 282 & 183 & 83 & 79 & 86 & 88 & 184 & 241 \\
\hline TOTAL & 3,477 & 3,166 & 3,183 & 2,835 & 2,824 & 1,906 & 3,048 & 2,170 \\
\hline
\end{tabular}

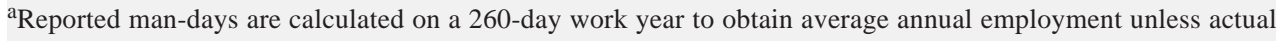
average annual employment numbers are provided.

${ }^{b}$ This figure does not include all of the man-days associated with peat operations; most of those man-days are included in sand and gravel numbers. 
\$8.3 million spent exploring for polymetallic massive sulfide deposits, and \$7.4 million spent on platinum-groupelement ultramafic deposits, epithermal gold deposits, epithermal uranium deposits, diamond, and other deposit types.

Advanced exploration projects include Placer Dome Inc.-NovaGold Resources Inc.-Calista Corp.'s 28.4-million-ounce Donlin Creek intrusion-hosted gold project and Northern Dynasty Minerals Ltd.'s Pebble copper-gold porphyry project in southwestern Alaska. The Pebble project, with newly announced measured and indicated resources of 54.8 million ounces of gold, 44.7 billion pounds of copper, and 2.7 million pounds of molybdenum, was the largest exploration project in 2005.

\section{Northern Region}

Teck Cominco Alaska Inc. drilled exploration targets in the area surrounding the Red Dog Mine. Drilling results were not announced, but several priority exploration targets remain around the mineralized systems at the Anarraaq, Aktigiruk, Paalaaq and Su Lik deposits and these targets may be drilled in 2006.

NovaGold Resources Inc. reported significant drill intersections from the Arctic deposit on its Ambler volcanogenic massive sulfide project in the Kobuk River area of the Brooks Range. The results from the nine-hole, 9,843-foot program confirmed additional high-grade copper and precious metal mineralization along the southeast margin of the deposit. Drill hole AR05-93 intersected three massive sulfide intervals with 7.4 percent copper equivalent over 69 feet, including 18.7 feet grading 3.1 percent copper, 0.017 ounces of gold per ton, 1.29 ounces of silver per ton, 0.6 percent lead, and 4.9 percent zinc or 6.5 percent copper equivalent and 17.7 feet of 4.4 percent copper, 0.009 ounces of gold per ton, 1.17 ounces of silver per ton, 0.8 percent lead, and 6.1 percent zinc or 8.4 percent copper equivalent. Drill hole AR05-97 intersected four massive sulfide intervals with 9.1 percent copper equivalent over 49.5 feet, including 28.5 feet of 3.5 percent copper, 0.014 ounces of gold per ton, 1.55 ounces of silver per ton, 1.2 percent lead, and 5.9 percent zinc or 7.7 percent copper equivalent; and 14.4 feet of 5.7 percent copper, 0.018 ounces of gold per ton, 1.70 ounces of silver per ton, 0.1 percent lead, and 2.1 percent zinc or 7.7 percent copper equivalent.

NovaGold also systematically evaluated existing data in the Ambler district, staked additional mining claims in the Ambler district, collected Arctic deposit ore samples for metallurgical testing, initiated engineering studies for transportation and power, and conducted baseline environmental studies.

Little Squaw Gold Mining Co. had a small exploration program on the Chandalar property, with work concentrated on ten gold quartz vein prospects. Work included geologic mapping and 189 rock, soil, and stream sediment samples were taken for analysis. At the Pallasgreen prospect, gold mineralization was found along a multiple quartz vein system for approximately 400 feet. Anomalous soil and rock results were also found in the Drumlummon area and in an unnamed quartz vein north of the Pallasgreen prospect. Further work at the Pioneer, Crystal, and Uranus prospects established drill targets at each site. Prospect mapping was started at the Little Squaw, Eneveloe, Grubstake West, Rock Glacier, and Summit areas. Little Squaw quartz vein rubble

Figure 1. Projects shown on this map represent $\$ 99.8$ million of the $\$ 100.9$ million spent on exploration in Alaska during 2005.

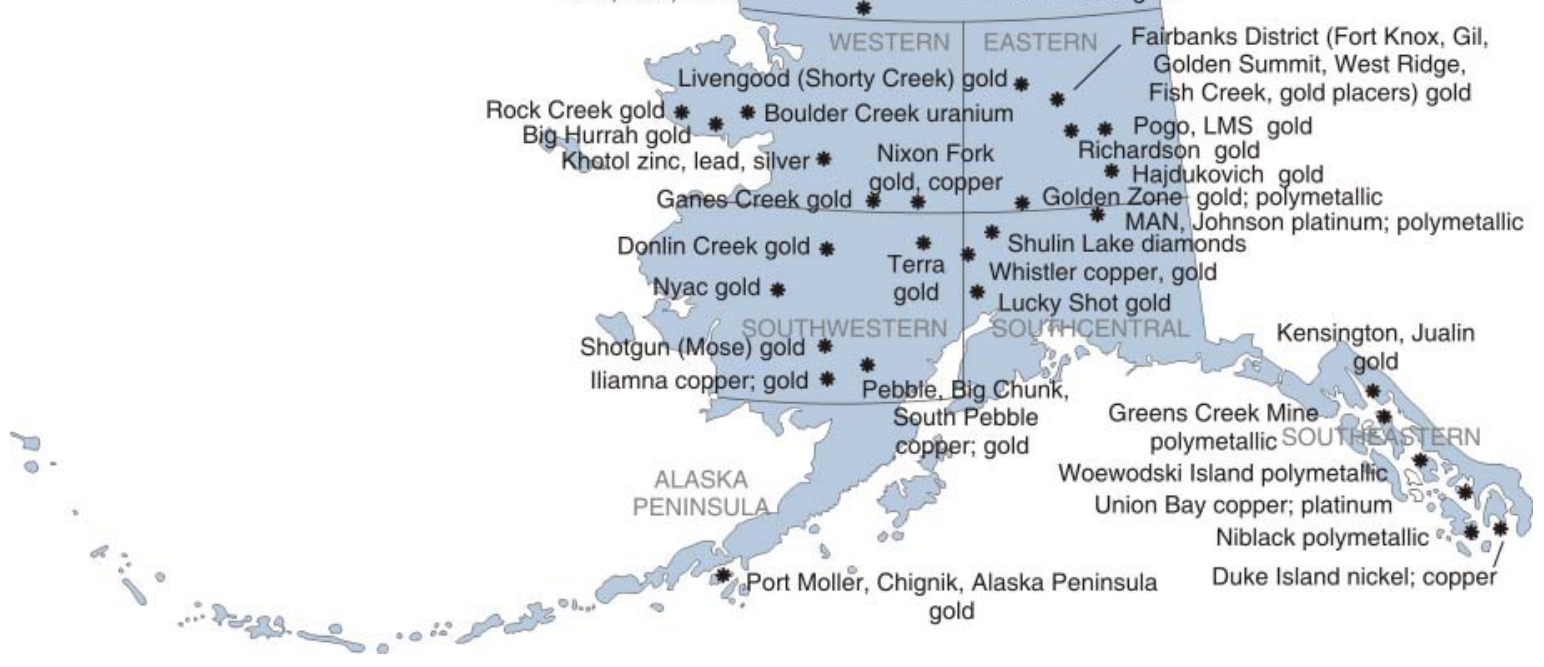


was traced about 2,500 feet eastward from the known exposures and geologic mapping indicates that at least two mineralized quartz veins continue in that direction.

\section{Western Region}

NovaGold Resources Inc. drilled the Big Hurrah property near Nome to develop a higher-grade resource on the project that can be integrated into the proposed Rock Creek mine plan. Environmental baseline work was also initiated at the Big Hurrah project to include the deposit in the Rock Creek permit process. Exploration drilling continued on the Rock Creek project, with a total of 32,500 feet of drilling at the Big Hurrah and Rock Creek areas.

NovaGold acquired the Khotol Project near the Yukon River and approximately 3 miles northeast of the recently reclaimed Illinois Creek open-pit gold mine in 2004. Highgrade silver and associated base metal mineralization occurs as disseminated to massive sulfide replacement style bodies along a regional dolomitic limestone-quartzite contact. During 2004 and 2005 a series of geophysical surveys were completed, including gravity and wide-spaced poledipole induced polarization (IP). Multiple kilometer-scale geophysical targets occur over a 2-mile by 1-mile area that is coincident with the two main soil anomalies identified by earlier work. Drilling totaled 3,937 feet. No results were announced.

Triex Minerals Corp. and Full Metal Minerals Ltd. jointly managed and conducted exploration on the Boulder Creek (formerly called Death Valley) project, the largest known uranium deposit in Alaska. The project area is on the southeastern Seward Peninsula. The deposit is a sandstone-type 'roll-front' deposit with predominantly epigenetic mineralization. Uranium was leached from a Late Cretaceous alkalic quartz monzonite and deposited in roll-fronts mode within a reducing environment of Paleocene, arkosic, carbonaceous conglomerates, and

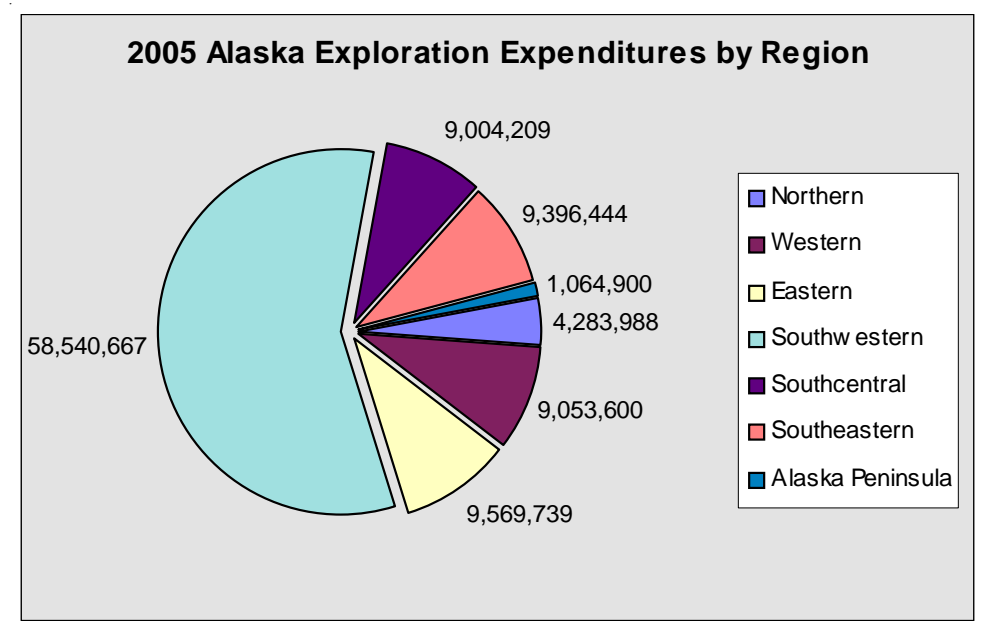

Figure 2. 2005 exploration expenditures in Alaska by region. sandstones of the Boulder Creek Basin. An extensive program of geologic mapping, ground scintillometer mapping, prospecting and grid-based soil sampling and biogeochemistry commenced in August after a joint-venture agreement was signed in mid year. Geochemical sampling totaled 23.5 line-miles covering a strike length of approximately 5.6 miles. A total of 1,180 samples were collected and analyzed. Several new geochemical anomalies were identified, suggesting potential extensions along strike to the existing deposit, as well as potential new deposits along the same granite-sandstone contact. Drilling is planned for early 2006.

Triex and Full Metal Minerals executed a second jointventure agreement to cover the 10.5 square mile McCarthy Marsh claims, located approximately 15 miles to the southwest of Boulder Creek and approximately 24 miles north of the coastal town of Elim. Limited work was done in 2005, but airborne geophysics and follow-up ground work is planned for the McCarthy Marsh claim block and surrounding area in 2006.

Full Metals Minerals Ltd. and Fury Explorations Ltd. signed a joint-venture agreement to explore the Ganes Creek gold property northeast of McGrath. The companies completed seven core holes totaling 4,109 feet. Four different zones were targeted along 1.75 miles of strike length proximal to the Yankee-Ganes Fault zone. Significant gold mineralization was encountered at the Katz Zone in hole GC05-54 that intersected 50 feet averaging 0.07 ounces of gold per ton, including 25 feet averaging 0.13 ounces of gold per ton. Mineralization occurs as quartz stockwork veins with sulfides in felsic and mafic dikes intruding hornfelsed sedimentary rocks. Other zones tested include two holes completed at the Independence Mine, one hole at the Independence northwest extension, two holes at the Hill 38 target, and two holes at the Katz Prospect. Long intervals of anomalous gold were intercepted in the drill holes near the Independence Mine and the Hill 38 prospect. Exploration also included collecting 328 soil samples, extending the soil grid coverage 1.2 miles to the southwest.

Mystery Creek Resources Inc., a subsidiary of St. Andrew Goldfields Ltd., continued exploration on the Nixon Fork gold-copper skarn property near McGrath. Core drilling focused primarily on the C3000 and C3300 ore chutes at the Crystal Mine, although some drilling was done late in the year in the Mystery Mine. Drilling included 25,333 feet of underground drilling and 11,047 feet of sur- 
face drilling. Several new exploration areas were explored with interesting intersections that will require follow-up. Geoinformatics Exploration Inc. provided new geophysical interpretations useful for resource modeling and surface exploration. An underground winter 2006 diamond drilling program at the Mystery Creek deposit is intended to delineate and confirm additional ore zones that will provide feed for the Nixon Fork operations.

Linux Gold Corp. staked three claim blocks in the Granite Mountain area of the Seward Peninsula for gold, base-metal, and uranium mineralization. Fieldwork in 2005 included geologic mapping and geochemical sampling of rocks, soils, stream sediments, and pan concentrates. Visible gold can be panned on the Kiwalik River. Geochemical sampling results indicated that polymetallic mineralization can be traced for 8 miles on the Kiwalik and Peace claim blocks.

\section{Eastern Region}

Teck Cominco Inc. restarted gold exploration on the Pogo property along with extensive development work on the underground Pogo Mine and associated facilities. A new mineralized vein system was discovered on the Chorizo prospect, 7.5 miles east of the mine area, during drilling of this and several other prospects. Additional drilling on the Chorizo Zone and other new targets is planned for 2006.

AngloGold Ashanti (USA) Exploration Inc. announced a significant Pogo-type gold discovery between Pogo and Delta Junction at the LMS property. Airborne geophysics and soil geochemical sampling programs outlined an area of anomalous gold with coincident anomalous arsenic, antimony, tellurium, and bismuth values. Significant gold intercepts were obtained from 8,859 feet of core drilling on two parallel moderately dipping structural zones traced for 1,600 feet along strike. The best drill intercept was 11 feet grading 0.634 ounces of gold per ton.

Table 3. Reported exploration expenditures in Alaska by commodity, 1982-2005

\begin{tabular}{|c|c|c|c|c|c|c|c|c|}
\hline \multirow[b]{2}{*}{1982} & \multirow{2}{*}{$\begin{array}{c}\text { Base } \\
\text { metals }\end{array}$} & \multicolumn{2}{|c|}{ Polymetallic $^{\mathbf{a}}$} & \multirow{2}{*}{$\begin{array}{c}\begin{array}{c}\text { Precious } \\
\text { metals }^{\mathbf{b}}\end{array} \\
\$ 10,944,100\end{array}$} & $\begin{array}{c}\text { Industrial } \\
\text { minerals }\end{array}$ & \multirow{2}{*}{$\begin{array}{c}\begin{array}{c}\text { Coal } \\
\text { and peat }\end{array} \\
\$ 2,900,000\end{array}$} & \multirow{2}{*}{$\begin{array}{l}\text { Otherc } \\
\$ 15,300\end{array}$} & \multirow{2}{*}{$\begin{array}{c}\text { Total } \\
\$ 45,617,300\end{array}$} \\
\hline & & $\$$ & N/A & & $\$ \quad--$ & & & \\
\hline 1983 & $9,758,760$ & & N/A & $20,897,555$ & $2,068,300$ & $1,338,454$ & 70,000 & $34,133,069$ \\
\hline 1984 & $4,720,596$ & & N/A & $14,948,554$ & 270,000 & $2,065,000$ & 279,500 & $22,283,650$ \\
\hline 1985 & $2,397,600$ & & N/A & $6,482,400$ & - - & 270,000 & - - & $9,150,000$ \\
\hline 1986 & $1,847,660$ & & N/A & $6,107,084$ & 170,000 & 790,000 & -- & $8,914,744$ \\
\hline 1987 & $2,523,350$ & & N/A & $11,743,711$ & 286,000 & $1,150,000$ & 31,000 & $15,734,061$ \\
\hline 1988 & $1,208,000$ & & N/A & $41,370,600$ & 160,200 & $2,730,000$ & - - & $45,468,800$ \\
\hline 1989 & $3,503,000$ & & N/A & $43,205,300$ & 125,000 & 924,296 & 5,000 & $47,762,596$ \\
\hline 1990 & $5,282,200$ & & N/A & $57,185,394$ & 370,000 & 321,000 & 97,000 & $63,255,594$ \\
\hline 1991 & $4,789,500$ & & N/A & $34,422,039$ & 92,000 & 603,000 & 2,000 & $39,908,539$ \\
\hline 1992 & $1,116,000$ & 3,5 & 50,000 & $25,083,000$ & 25,000 & 425,000 & - - & $30,209,000$ \\
\hline 1993 & 910,000 & 5,6 & 76,743 & $23,382,246$ & 163,500 & - & 125,000 & $30,257,489$ \\
\hline 1994 & 600,000 & 8,0 & 99,054 & $18,815,560$ & 225,000 & $2,554,000$ & 810,000 & $31,103,614$ \\
\hline 1995 & $2,770,000$ & 10,5 & 0,000 & $20,883,100$ & 100,000 & - & 3,000 & $34,306,100$ \\
\hline 1996 & $1,100,000$ & 11,9 & 33,364 & $31,238,600$ & 400,000 & -- & - - & $44,721,964$ \\
\hline 1997 & $1,700,000$ & 22,3 & 47,000 & $32,960,500$ & 80,000 & 720,000 & - - & $57,807,500$ \\
\hline 1998 & $1,000,000$ & 13,7 & 27,000 & $42,441,000$ & 12,000 & 87,000 & - & $57,267,000$ \\
\hline 1999 & $3,869,000$ & 3,1 & 58,000 & $44,891,000$ & 1,000 & - & 410,000 & $52,339,000$ \\
\hline 2000 & $8,545,000$ & 3,9 & 33,000 & $21,579,000$ & 58,500 & - & 736,100 & $34,851,600$ \\
\hline 2001 & $4,810,000$ & 1,9 & 77,000 & $15,820,000$ & 50,000 & 10,000 & $1,106,000$ & $23,773,000$ \\
\hline 2002 & $1,700,000$ & 5,1 & 2,000 & $17,342,000$ & 185,000 & - - & $2,113,000$ & $26,502,000$ \\
\hline 2003 & 262,000 & 7,0 & 31,000 & $19,726,000$ & - & W & 533,000 & $27,602,000$ \\
\hline 2004 & $3,100,000$ & 40,2 & 37,000 & $26,954,000$ & 213,000 & 50,000 & 258,000 & $70,812,000$ \\
\hline 2005 & 655,000 & 54,8 & 30,000 & $44,523,000$ & 140,000 & - & 716,000 & $100,914,000$ \\
\hline Total & $\$ 99,925,566$ & $\$ 192,3$ & 31,161 & $\$ 632,945,743$ & $\$ 5,194,500$ & $\$ 16,937,750$ & $\$ 7,309,900$ & $\$ 954,694,620$ \\
\hline \multicolumn{9}{|c|}{$\begin{array}{l}\text { aPolymetallic deposits considered a separate categor } \\
\text { bApproximately } \$ 4.0 \mathrm{M} \text { spent on platinum-group-el } \\
\text { "Includes diamonds and tantalum. } \\
\text { N/A = Not available. } \\
\text { - - Not reported. } \\
\text { W = Withheld, data included in "Other" column. }\end{array}$} \\
\hline
\end{tabular}


Kinross Gold Inc. continued an aggressive explorationdrilling program in and around the existing Fort Knox open-pit gold mine near Fairbanks. Kinross flew an aeromagnetic survey during 2005 and identified additional targets to explore in 2006. Kinross also continued to evaluate the nearby Gil gold property. At year's end, the True North and Gil deposits were reclassified from reserves to resources and Kinross elected to withdraw from the Ryan Lode project.

Select Resources Corp., a wholly owned subsidiary of Tri-Valley Corp., conducted gold exploration at the Democrat Prospect and related prospective areas within the approximately 40-square-mile Richardson Property east of Fairbanks. Select Resources acquired and reviewed all records of previous exploration in the district, built a GIS database, and critically reviewed this past work in the field; acquired QuickBird high-resolution satellite imagery for the district, and completed district-scale interpretation of available satellite imagery; numerically modeled regional and district-scale public-domain airborne geophysical data; completed an auger soil geochemical survey along the trace of the Richardson lineament; and completed an eight-hole, 3,050-foot, diamond drilling program in the Democrat mine area. This work clarified the geologic setting of the district and highlighted a number of gold exploration targets. Soil sampling results showed anomalous gold concentrations, coincident with enriched silver, arsenic, bismuth, molybdenum, lead, antimony, and tungsten values occur in seven clusters, each approximately 1.2 miles in diameter, over the 4.3-mile length of the survey. Five drill holes tested an intensely altered, autobrecciated, and gold-mineralized felsic porphyry stock in the Democrat pit and the other three drill holes tested strike extensions of mineralization. Drilling results were not announced.
Select Resources also explored the Shorty Creek property in the Livengood mining district northwest of Fairbanks. Select interprets a cluster of pronounced magnetic highs shown on public airborne magnetic data over the Shorty Creek property as shallow-level intrusive stocks. A total of 566 soil samples were collected on an 80-foot by 330 -foot grid over an approximately 1.5-square-mile portion of the project. Initial results from 222 of these soil samples from the southern portion of the grid returned highly anomalous gold, silver, arsenic, bismuth, antimony, tellurium, and tungsten values. Gold in soil values in the grid range up to 0.033 ounces of gold per ton. Geochemical associations, geologic observations, and geophysical results are consistent with an intrusion-related gold mineralization model.

Freegold Ventures Ltd. completed a 1,270-foot trenching program at its Golden Summit property near Fairbanks. Six trenches were placed in a 1,000-foot-wide area south of the historic Cleary Hill Mine (historic production of 281,000 ounces of gold at an average grade of 1.28 ounces of gold per ton). Two district scale shear zones (Dolphin and Anna Mary) intersect in this area. Trench WZ-05-01 tested the mineralization within the 550 -foot area between 2002 trenches CU02-4/5/6 and CU02-3, while the remaining five trenches, WK-05-02 to WK-05-06, were placed to test the eastern strike extent of the zone, and to further test the continuity of high-grade veins encountered in the 2002 trenching. Two new 6- to 18-inch-wide gold-bearing veins were encountered in trench WZ-05-01. The northernmost of the two veins graded 0.835 ounces of gold per ton over 5 feet, with three grab samples from the vein grading 4.06 ounces of gold per ton, 0.65 ounces of gold per ton, and 0.35 ounces of gold per ton. The second vein was encountered 190 feet to the south, and graded

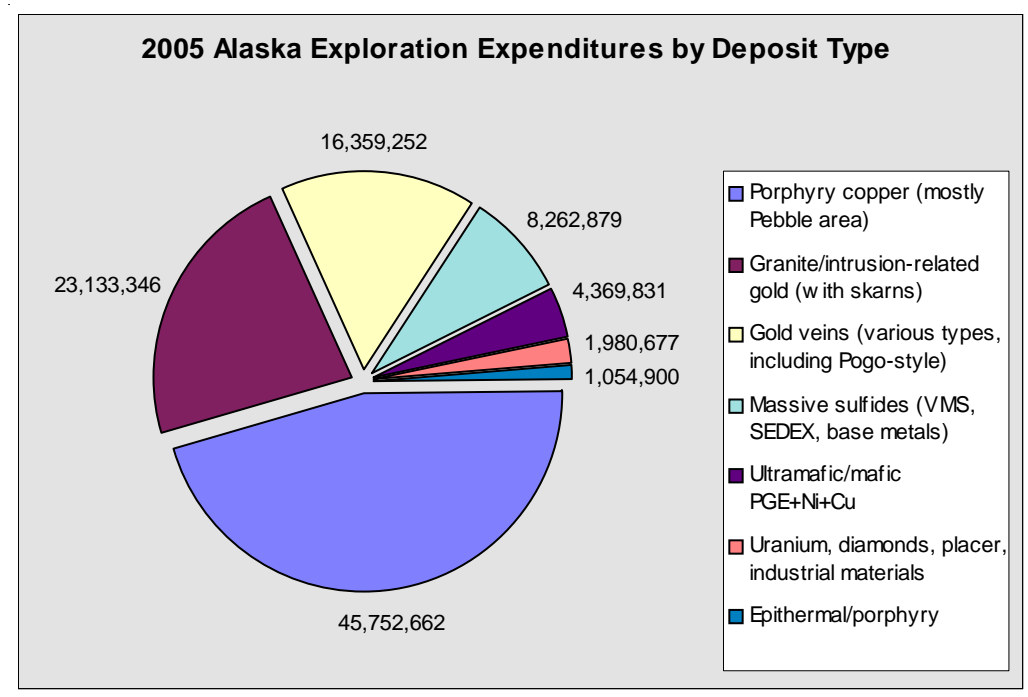

Figure 3. 2005 Alaska exploration expenditures by deposit type. 
1.03 ounces of gold per ton over 5 feet with one grab sample grading 1.86 ounces of gold per ton. Numerous other smaller quartz veins and sheeted quartz veinlets were exposed in the trenches. The Wackwitz vein was exposed in trench WZ-05-02, and the current trenching extended the known strike length of the Wackwitz vein to 730 feet. The shear zone hosting the vein in trench WZ-05-02 returned 10 feet grading 0.08 ounces of gold per ton. Native gold flakes up to 0.04 inch across were observed in the vein at this location. A total of 248 rock-chip samples were collected using a 5-foot sample interval taken along the center of each trench floor. Sampling along strike of the Wackwitz generated nine chip samples using 6.5-foot spacing. An additional 31 grab samples were taken from selected veins.

Caneco Resources Inc. signed a joint-venture agreement with Teck Resources Inc. to earn a 100 percent working interest in the Hajdukovich and Macomb gold properties. Work on the Hajdukovich property included rock sampling at the Sneaker, UPEG Saddle, and PW zones. Mineralization at the Sneaker Zone consists of gold in sheeted quartz veins; disseminated sulfides in altered granites occur at the UPEG Saddle Zone; and some massive sulfide lenses occur at the PW Zone. Three core holes totaling 1,516 feet were drilled at the Sneaker Zone. The drill holes did not reach target depths, but some core intercepts with anomalous gold and bismuth values were altered and sheared. Minimal work was done on the Macomb property.

\section{Southcentral Region}

Kennecott Exploration Co., a Rio Tinto Group company, made a significant copper discovery at the Whistler prospect near Rainy Pass. Mineralization occurs as extensive lower grade and "quite attractive" higher grade. Kennecott drilled 12 holes that intersected broad intervals of copper and gold, along with silver and molybdenum. Preliminary metallurgical testing showed much of the gold is contained in a copper concentrate. Kennecott identified eight other targets similar to the Whistler prospect in the surrounding area, and three of four targets tested had copper-gold mineralization.

Full Metal Minerals Ltd. explored the historic Lucky Shot gold mine property in the Willow Creek mining district. The property has excellent access to roads, infrastructure, and power. The Lucky Shot Mine was the richest gold producer in the Willow Creek mining district, with grades ranging from 2.0 to 4.0 ounces of gold per ton. Gold-bearing quartz veins and structures at Lucky Shot occur within a granitoid batholith. In July, Full Metal completed a seven-hole, 3,018-foot diamond drilling program to test the updip potential of the Coleman/Lucky Shot shear zone, approximately 800 feet updip of historic workings and 800 feet along strike. All drill holes intersected the Lucky Shot Shear, which is typified by strong chlorite- sericite-carbonate alteration, brecciation, and silicified cataclasites. This structure is wide open for expansion to the northwest and west with limited potential to the south. Drill hole C05-12 intersected 7.0 ounces of gold per ton over a 13.1-foot true width (uncut), including 37.0 ounces of gold per ton over a 2-foot true width. Hole C05-12, a 164-foot step-out hole to the west of hole C05-09, had a 10 -foot true width intersection averaging 1.82 ounces of gold per ton. Intercepts in C05-13, located 230 feet updip on C05-12, showed a continued strong shear zone, similar to gold-rich portions of the Lucky Shot system. Full Metal expanded the Lucky Shot property to the north, west, and south by staking 28 State mining claims.

Anglo American Exploration (USA) Inc. explored the 150-square-mile Area 1 (Fish Lake-Dunite Hill Area) of Nevada Star Resource Corp.'s 271-square-mile MAN property. Anglo American completed ground electromagnetic surveys over multi-element soil anomalies identified in 2004, structural and geologic mapping, and soil geochemical sampling. A total of 7,330 feet of drilling was completed in eight holes. Drilling tested geophysical, geochemical, and geological anomalies near exposures of nickel-copper (platinum-group-element) sulfide showings and sulfide gossans within the Fish Lake Ultramafic Complex. The best assay results were for drill holes 1, 6, and 8. Drill hole 8 tested strong multi-element geochemical anomalies associated with a sulfide gossan, 0.6 miles long by 500 feet wide, in the center of a large interpreted Kambalda-like footwall embayment feature along the base of the Fish Lake Complex. The drill hole encountered massive iron-nickelcopper sulfide mineralization within ultramafic rock, approximately 230 feet upsection of the basal contact. Assay results included 0.97 percent nickel and 0.14 percent copper over 3.3 feet, including 3.22 percent nickel and 0.38 percent copper over 9 inches from 500 feet depth and a 1-inch-thick massive sulfide zone calculated to contain 12 percent nickel. Drill hole 6 tested strong multi-element geochemical anomalies at the west end of the embayment feature tested by drill hole 8 . Assay results included a 40foot-thick intercept grading 0.27 percent nickel and 0.06 percent copper from 1,180 feet, including 0.39 percent nickel and 0.05 percent copper over 5 feet. Drill hole 1 was drilled in the footwall to the Tres Equis massive sulfide showing and encountered disseminated sulfide mineralization, including a 109-foot-thick intercept grading 0.31 percent nickel, 0.14 percent copper and 0.006 ounces of platinum-group-elements per ton from 340 feet depth, with a 7 -foot intercept grading 0.50 percent nickel, 0.23 percent copper, and 0.012 ounces of platinum-groupelements per ton.

Overall, the 2005 drilling results, combined with historical drilling and exploration results, suggest the presence of several diffuse kilometer-scale zones of weak disseminated sulfide mineralization within the Fish Lake Complex. 
This low-grade mineralization could provide a vector to structural traps with high-grade massive sulfide deposits. Additional ground electromagnetic and magnetic geophysical surveys and soil and rock geochemical surveys were completed after the drill program by Anglo American to delineate drill targets for 2006.

Nevada Star Resource Corp. also explored their portion of the MAN property not under joint-venture agreement with Anglo American. One hundred thirty rock samples were collected in the 2005 program for geochemical analysis. Nevada Star also staked 260 Federal mining claims to add to the MAN property.

Alaska Range Minerals Corp., a subsidiary of bcMetals Corp., was granted on option to acquire 100 percent ownership of a 9-square-mile block of mineral claims situated in the Alaska Range referred to as the Johnson property. The Johnson property is accessible by road from the Richardson Highway and approximately 175 road miles southeast of Fairbanks. The Johnson property hosts several identified prospects and more than 40 mineral occurrences on which very little exploration has been conducted. Metallic mineralization is of two main types: magmatic copper-nickel-platinum-group elements; and porphyry or volcanogenic massive sulfide copper-goldsilver-lead-zinc. Field mapping and soil and rock geochemical sampling were completed. Core drilling of five holes, totaling approximately 1,600 feet, was completed on three prospects, but heavy snow cover hampered drilling. No significant mineralization was encountered.

Piper Capital Inc. announced a new independent mineral resource estimate prepared by Norwest Corp. for its Golden Zone gold-silver-copper deposit. The property is 9 miles from the Alaska Railroad and the paved George Parks Highway on the south side of the Alaska Range. The Golden Zone deposit contains measured and indicated resources of approximately 2 million tons, grading 0.106 ounces of gold per ton, 0.47 ounces of silver per ton and 0.12 percent copper (utilizing a 0.05 ounces of gold per ton cut-off grade), and contains approximately 214,800 ounces of gold, 948,000 ounces of silver and 24,000 pounds of copper. Piper Capital drilled a total of 10,500 feet at the Golden Zone project in 19 core holes and one reversecirculation hole during 2005. Twelve holes focused on the Golden Zone Breccia Pipe, six holes were drilled on the BLT Zone, one hole was drilled on the Mayflower Zone, and one hole was drilled at the Long Creek gold-copper prospect. All drill holes intersected gold mineralization. Significant results included: hole 50.5E-1with a 135.5-foot intercept grading 0.06 ounces of gold per ton at 325 feet depth and a 110-foot intercept grading 0.03 ounces of gold per ton at 625 feet depth within the Golden Zone Breccia Pipe, hole 61E-1, within the Mayflower Zone 984 feet northeast of the Golden Zone Breccia Pipe, with a 14.8foot intercept grading 0.05 ounces of gold per ton at a depth of 88.6 feet, hole 43.3E-1, in the BLT Zone 328 feet to the southwest of the Golden Zone Breccia Pipe, with a 24.6foot intercept grading 0.03 ounces of gold per ton at a depth of 220 feet, and hole 47.3E-2, mainly in the Golden Zone Breccia Pipe, with a 408-foot intercept grading 0.13 ounces of gold per ton starting at 298 feet depth, including a 16.7foot intercept grading 0.58 ounces of gold per ton, 2.54 ounces of silver per ton, and 0.22 percent copper starting at 323 feet depth.

Piper Capital Inc. staked 110 contiguous State of Alaska mining claims near Mt. Estelle and immediately south of Kennecott's Whistler land package. Mineralization in the Mt. Estelle area is related to composite alkalic intrusions of late Cretaceous age ranging in size from small cupolas to the Mt. Estelle batholith. Reconnaissance sampling in August 2005 in the South Estelle project area confirmed mineralization in two previously known prospects, Ultramafic and the Revelation Vein, and identified three new prospects designated Shoeshine, Train, and Saddle. A mineralized intrusion sample from the Ultramafic prospect assayed 3.29 ounces of gold per ton, 7.15 ounces of silver per ton, and 0.13 percent copper. Samples from a 656foot-long vein at the Revelation Vein prospect assayed 0.95 ounces of gold per ton, 0.24 ounces of silver per ton, and 0.10 percent copper, and 0.21 ounces of gold per ton, 0.37 ounces of silver per ton, and 0.16 percent copper. A sample from a sulfide boulder train in moraine at the Train prospect assayed 0.70 ounces of gold per ton, 2.67 ounces of silver per ton, and 0.33 percent copper. A sample from a mineralized dike traced for 1 mile along strike at the Saddle prospect assayed 0.21 ounces of gold per ton, 0.06 ounces of silver per ton, and no reported copper content.

A joint venture between Golconda Resources Ltd., Shulin Lake Mining Co., and Shear Minerals Ltd. explored the Shulin Lake property for diamonds. Core drilling tested a series of geophysical anomalies chosen from a reinterpretation of existing geophysical data. Five holes were drilled to test three magnetic anomalies interpreted as being potential pipes. Nine samples with a total weight of 5,291 pounds were submitted to SGS Lakefield Research for testing and contained one micro-diamond and diamond indicator minerals in a volcanic tuff sequence. One white, transparent diamond fragment was recovered from sample B3 of drill hole 25. The dimensions of the diamond are 0.02 inch x 0.01 inch x 0.006 inches. Golconda staked additional claims and dug three 6-foot-deep pits in a circular negative anomaly of about 0.6 miles in diameter. The anomaly is coincident with a circular swamp visible on satellite photos. The pits were sampled and each sample weighed approximately 20 pounds. Although these samples were taken from glacial till, visual observation of the concentrates showed green chrome diopside, kyanite, sapphire, rutile, and anatase. Golconda plans to excavate the area of the pits in early 2006 and drill within this interpreted volcanic vent or pipe. 


\section{Southwestern Region}

Northern Dynasty Minerals Ltd. conducted the largest exploration project in Alaska during 2005 at the Pebble project near Lake Iliamna. The project consists of 1,331 State of Alaska mining claims covering 153 square miles. Northern Dynasty acquired a 100 percent working interest in the Pebble property (subject to a maximum 5 percent Teck Cominco net profits interest in the exploration lands portion of the property) early in 2005. The Pebble deposit is a calc-alkalic porphyry with quartz stockwork veins containing principally pyrite, chalcopyrite, and molybdenite in the intrusion(s) and sedimentary host rocks.

In early 2005 Northern Dynasty announced a new mineral resource for the Pebble deposit prepared by Roscoe Postle Associates Inc. The new resources include measured and indicated resources of 3.335 billion tons grading 0.28 percent copper, 0.009 ounces of gold per ton, and 0.015 percent molybdenum containing 31.3 million ounces of gold, 18.8 billion pounds of copper and 993 million pounds of molybdenum. An additional inferred resource includes 1.245 billion tons grading 0.24 percent copper, 0.0088 ounces of gold per ton, and 0.014 percent molybdenum containing 10.8 million ounces of gold, 5.8 billion pounds of copper and 361 million pounds of molybdenum, using a 0.30 percent copper-equivalent cutoff grade.

A substantial high-grade porphyry deposit was discovered by Northern Dynasty in 2004 adjoining the Pebble deposit on the east. Exploration for additional coppergold-molybdenum porphyry-style mineralization in 2005 concentrated on the East Zone of the project area, with the mineralized intrusion capped by at least 1,500 feet of Tertiary volcanic cover. Drilling was completed in 39 holes with a total drilling footage of 60,856 feet. Some highlights of the drilling are seen in drill holes 5332, 5335, and 5336. Drill hole 5332 intersected 2,367 feet grading 1.41 percent copper equivalent, comprising 0.89 percent copper, 0.01 ounces of gold per ton, and 0.055 percent molybdenum. Included in this intersection is an 817 -foot interval grading 1.74 percent copper equivalent (1.28 percent copper, 0.008 ounces of gold per ton, and 0.05 percent molybdenum). Drill hole 5335 intersected 2,478 feet grading 0.81 percent copper, 0.013 ounces of gold per ton and 0.023 percent molybdenum. Drill hole 5336 intersected 2,584 feet grading 0.67 percent copper, 0.007 ounces of gold per ton and 0.055 percent molybdenum, including 150 feet grading 1.16 percent copper, 0.021 ounces of gold per ton and 0.059 percent molybdenum. The East Zone deposit is open to expansion to depth and in all lateral directions. A deep drilling program to fully delineate the East Zone started in March 2006 with four drill rigs.

Northern Dynasty Minerals announced an initial mineral resource estimate, audited by Roscoe Postle Associates, for the East Zone deposit at its Pebble project. At a 0.60 percent copper-equivalent cutoff, the estimated inferred mineral resources are 2.02 billion tons grading 1.05 percent copper equivalent containing 24.3 billion pounds of copper, 22.1 million ounces of gold and 1.5 billion pounds of molybdenum. At a 1 percent copper-equivalent cut-off, the higher grade inferred mineral resources are estimated at: 1.04 billion tons grading 1.28 percent copper equivalent containing 16 billion pounds of copper, 14.5 million ounces of gold and 830 million pounds of molybdenum. The East Zone resource estimate is a significant increase in copper, gold, and molybdenum resources for the overall Pebble project and substantially augments its higher grade resources. The East Zone deposit is contiguous with the Pebble deposit (now called Pebble West Zone deposit) and will be assessed for its amenability to low-cost, bulk underground mining. The East Zone deposit is open to expansion in all lateral directions and to depth. The Pebble West Zone porphyry copper-gold-molybdenum deposit is being studied at the feasibility level as an open-pit mine.

Exploration work on the Pebble property also included extensive environmental studies and community outreach, with $\$ 18$ million budgeted for these activities in 2005. Two years of environmental baseline data have been collected. Forty-five consulting firms, with a total workforce of 441 Alaskans, worked on the project during 2005. During 2005, thirty-three mine site surface water stations and 350 fish sampling and survey locations were sampled. Approximately 198 square miles were surveyed as part of the wetlands delineation program. There were 300 stakeholder/ community outreach meetings in 2005 compared to 64 meetings in 2004, and 25 communities in the Bristol Bay region were visited.

Placer Dome Inc. continued an extensive drill program on the Donlin Creek Project near Aniak. Three diamond core drill rigs completed 75,548 feet of infill drilling and 2,766 feet of geotechnical drilling. Reverse-circulation drilling, totaling 15,020 feet, was completed for condemnation, water, and calcareous sandstone testing for tailings neutralization uses. Placer Dome also completed detailed engineering and design studies for all capital and operating cost estimates to a prefeasibility level. Wind monitoring instruments were installed and data collected to study the potential of local power generation. More than 15 tons of material was shipped offsite for bench and pilot test work. Extensive baseline environmental work, including habitat, fisheries, and waste characterization studies, along with the ongoing water quality studies, continued in preparation for formal permit applications to be filed by early 2006.

NovaGold Resources Inc., joint-venture partner with Placer Dome, reported results from the infill drill program on the Donlin Creek project. Drilling was completed to upgrade inferred gold resources to measured and indicated gold resources, as well as geotechnical and condemnation drilling. Significant assay results from the drilling are extensive. DC05-1013 had five mineralized intervals totaling 
528.2 feet of 0.18 ounces of gold per ton, including 95.1 feet grading 0.37 ounces of gold per ton. DC05-1018 had eight mineralized intervals totaling 910.4 feet of 0.11 ounces of gold per ton, including intervals of 212.3 feet grading 0.16 ounces of gold per ton and 92.9 feet grading 0.18 ounces of gold per ton. DC05-1033 had four mineralized intervals totaling 295 feet of 0.19 ounces of gold per ton. DC05-1033 had four mineralized intervals totaling 295 feet of 0.19 ounces of gold per ton. DC05-1053 had five mineralized intervals, totaling 374 feet, and grading 0.17 ounces of gold per ton, including 144.4 feet grading 0.22 ounces of gold per ton. DC05-1063 had seven mineralized intervals totaling 339.3 feet of 0.20 ounces of gold per ton, including intervals of 39.4 feet grading 0.48 ounces of gold per ton and 67.9 feet of 0.23 ounces of gold per ton. DC05-1065 had nine mineralized intervals totaling 847.2 feet of 0.15 ounces of gold per ton, including intervals of 82 feet grading 0.30 ounces of gold per ton, 97.4 feet of 0.21 ounces of gold per ton, and 216.2 feet grading 0.17 ounces of gold per ton.

A new gold resource for the Donlin Creek project was announced in January 2006 by Placer Dome. The new resource estimate significantly increased the measured and indicated resource compared with 2003 resource estimates. The measured and indicated resource, using a 0.035 ounces of gold per ton cut-off grade, increased 3.7 million ounces or 33 percent to 14.8 million ounces of gold grading an average of 0.08 ounces of gold per ton. The inferred resource decreased by 0.7 million ounces to 13.6 million ounces of gold grading 0.0794 ounces of gold per ton through conversion to the measured and indicated category. This mineral resource is constrained within a potentially economic pit model. The Donlin Creek Joint Venture expects to complete a prefeasibility level study by mid 2006 and began a feasibility drill program in February 2006.

Liberty Star Gold Corp completed drilling and other fieldwork on the 421-square-mile Big Chunk project. The Big Chunk claims adjoin Northern Dynasty's Pebble project on the north border, forming a large donut shape and adjoining their border to the southeast. Fieldwork included collecting 153 stream-sediment geochemical samples, 1,702 vegetation samples, 147 line-miles of line surveying and clearing, 99 miles of induced polarization (IP) geophysics, and 27 diamond core drill holes totaling 10,948 feet. A new geologic interpretation showed two ages of volcanic rocks on the property, one pre-mineral in age and one post-mineral in age. The pre-mineral volcanic rocks are exposed or thinly covered over a very large area and are interpreted to be part of a large caldera responsible for mineral bodies in the Big Chunk area. This summer's work included further encouraging results from the White Sox copper-molybdenum porphyry center, discovered a new porphyry center at the Baltusrol prospect, discovered gold mineralization over a 5.7-mile by 2 -mile area at the $\mathrm{Au}$ - gusta prospect, identified new geochemical anomalies untested by geophysics or drilling, and identified several IP geophysical anomalies untested by drilling.

Drilling results on the Big Chunk property were positive at several prospects. Hole 15 in the Baltusrol area intercepted 50 feet of 0.1 percent copper and 0.0018 ounces of gold per ton, from 686.0 feet to 736.0 feet. Hole 12 intercepted several intervals containing up to 0.12 percent copper, up to 0.014 percent molybdenum, and up to 0.0025 ounces of gold per ton. Induced polarization anomalies continued north from the Baltusrol prospect into the Point Grey prospect area. Hole 23, in the Point Grey area, intercepted 0.0078 ounces of gold per ton over a total of 177 feet including 10 feet of 0.059 ounces of gold per ton. Associated minerals indicate that this is a gold-silver system.

Liberty Star Gold Corp staked 94 State of Alaska mining claims over a promising gold target about 40 miles northeast of the northern boundary of the Big Chunk claim block. The Bonanza Hills project area covers a dome-like feature consisting of a granitic stock intruding Cretaceous age sediments. The sediments are pervasively altered, contain finely disseminated sulfides, and are quartz veined. Previous gold placer workings are present on the property. Initial sample results from quartz veins had anomalous gold values ranging from 0.02 ounces of gold per ton up to 3.11 ounces of gold per ton. Additional rock-chip and soil sampling was completed but results were not announced. Preliminary geologic mapping was also done over a broad area.

AngloGold Ashanti (USA) Exploration Inc. announced a significant high-grade gold discovery at the Terra property northeast of Lime Village. High-grade quartz veins, up to 8 ounces of gold per ton in rock-chip samples, occur along a 5-mile structural zone with porphyry-epithermal style mineralization. Five targets, each with soil sample results up to 0.146 ounces of gold per ton were identified in 2005. Twelve core holes totaling 6,562 feet were drilled on three targets. Hole TR05-01 in the Ben Zone had a 3.6foot intercept grading 4.11 ounces of gold per ton. A 1-foot intercept in hole TR05-07 from the Fish Creek Zone graded 3.75 ounces of gold per ton. Early assay results from the four main vein zones indicated average gold values in the 0.58 ounces of gold per ton range over nominal 3 to 7 foot widths, with near-surface stockwork zones ranging from 33 to 66 feet wide with grades averaging 0.07 ounces of gold per ton.

TNR Gold Corp. expanded known intrusion-related gold mineralization at the Shotgun property during 2005 with a geochemical sampling program. TNR completed a total of 1,754.3 feet of diamond drilling in six holes on the Winchester Zone, the southernmost target of the Shotgun project, approximately 11 miles south of the main Shotgun Zone. The best geochemical results were in hole DDH05-32, collared in a medium-grained felsic intrusion 
that averaged 0.047 ounces of gold per ton over 46 feet, including 0.115 ounces of gold per ton over 6.8 feet from the surface to the contact with Kuskokwim sediments. All drill holes from 2005 contained anomalous gold values associated with anomalous arsenic, bismuth, copper, and tungsten values.

TNR Gold Corp. and Geocom Resources Inc. continued exploration at the $\mathrm{D}$ and $\mathrm{H}$ claims on the Iliamna project. Furio Resources completed an induced polarization survey and a ground magnetic survey on their property in the Pebble area. The results of the surveys were inconclusive.

Full Metal Minerals Ltd. completed approximately 15.5 line miles of IP geophysics in the BOO and TYP prospect areas of the Pebble South property. Full Metal also collected 103 soil samples to refine the geophysical and geochemical targets identified in 2004. Additional claims were staked to the west of the KAK claims (northern block) covering an airborne magnetic anomaly.

Tonogold Resources Inc., in partnership with Calista Corp., defined six large disseminated gold prospects in the Nyac mining district during 2005 with a soil geochemical survey covering a 5.8-square-mile area. Initial grid spacing was 200 feet by 400 feet, followed by 100 foot by 100 foot spacing in selected areas. Numerous soil values of more than 0.015 ounces of gold per ton and multiple values in excess of 0.03 ounces of gold per ton were found in each prospect area. The highest soil assay reported was 0.12 ounces of gold per ton and the highest rock-chip value was 0.44 ounces of gold per ton. Anomalous gold results are in Cretaceous intrusions and Jurassic volcanic and volcaniclastic rocks. Tonogold plans a 20,000-foot core drill program, a 5,000-sample soil program, a helicopterborne aeromagnetic survey, and district-wide geologic mapping for 2006.

\section{Alaska Peninsula Region}

In June 2005, Full Metal Minerals Ltd. initiated an exploration program in the Port Moller region, consisting of surface mapping, sampling, and IP geophysics on the Unga and Popov Islands epithermal gold targets, as well as the Pyramid copper-gold prospect. A total of 339 surface samples, including 22 soil, 15 stream sediment and 302 rock samples, were taken on a variety of prospects during 2005. On Unga and Popov islands, exploration focused on evaluating historic epithermal gold showings. On Unga Island, mapping of a 4-mile-long northeast structural corridor hosting strong alteration and anomalous gold and silver mineralization refined the stratigraphic and structural geologic setting, and identified multiple drill targets. IP surveys identified local areas of strong resistivity. At the Centennial deposit on Popov Island, IP geophysics identified a steeply dipping resistivity and coincident chargeability anomaly at depth that could be a potential feeder zone within basement rocks to the near-surface disseminated gold mineralization. A clay mineralogy study at multiple target areas identified several areas of high-temperature clay alteration, of both high and low sulfidation affinity. At the Pyramid copper-gold-molybdenum porphyry, mapping, grid geochemical sampling, and five lines of IP geophysics and ground magnetic surveys were completed. Despite poor local ground conditions for the IP survey, a large chargeability anomaly was identified, coinciding with the untested potassic core of the porphyry. Satellite remote sensing identified an area with strong hightemperature clay alteration at an unexplored area south of the historically drilled area. An IP survey, as well as mapping and sampling, were completed on the Zachary Bay porphyry target on Unga Island. A weak chargeability anomaly was coincident with a widespread color anomaly and weakly anomalous geochemical sample results.

Full Metal Minerals Ltd. signed an agreement with the Bristol Bay Native Corp. to exclusively explore approximately 565,000 acres of the Alaska Peninsula. This area is prospective for epithermal gold and porphyry copper-gold deposits. Metallica Resources Inc. subsequently entered into an option agreement with Full Metal Minerals to earn a 65 percent interest in the Aleutian Islands and Alaska Peninsula properties controlled by Full Metal. In July 2005, Full Metal and Metallica Resources, after negotiating a joint-venture agreement, initiated surface mapping, sampling, and IP geophysics on historic showings located on Native-owned lands in the Chignik area. Work was performed on five porphyry copper-gold-molybdenum systems. The most encouraging prospects include Bee Creek, Kawisgag and Mallard Duck. A total of 457 surface samples, consisting of 294 soil, 48 stream sediment and 115 rock samples, were taken on a variety of prospects during 2005. Three pole-dipole IP lines were surveyed at Bee Creek during 2005. All three IP lines show strong chargeability anomalies in a zone centered on historic drill hole B-5, located in the valley floor. One IP and magnetic line was completed along the bench above the Weird Duck Breccia area of the Mallard Duck prospect, and two strong chargeability anomalies were identified.

\section{Southeastern Region}

Joint-venture partners Lonmin Plc, Pacific North West Capital Corp., and Freegold Ventures Ltd. continued aggressive exploration for platinum-group elements at the Union Bay ultramafic complex near Ketchikan. The 2005 exploration program focused on several areas identified from last year's airborne magnetic survey and the ground magnetic survey completed earlier this year. A 10,000-foot drill program tested a number of these targets within these prospective areas but did not identify significant followup targets. Lonmin opted to terminate its interest in the property. 
Niblack Mining Corp. explored the copper-gold-rich Niblack massive sulfide property on Prince of Wales Island in southeastern Alaska. The exploration program included 6,200 feet of diamond drilling in seven drill holes and re-established environmental baseline studies. The drill program focused on the Lookout Zone, the most advanced area of the five known zones of massive sulfide mineralization on the property. A new exploration model includes multiple stacked massive sulfide lenses with predictable geometries and plunge directions and showed excellent potential for expanding known zones, as well as discovering new sulfide lenses.

All seven drill holes in the Niblack drill program intersected significant mineralization, with several holes yielding multiple high-grade intervals. Four holes intersected wide zones of near-surface gold and silver oxide mineralization that overlie zones of precious-metal-enriched sulfide mineralization at depth. Continuous intersections of combined oxide and sulfide mineralization range in width from 86.4 feet to 145.6 feet, and yield an arithmetic average of 0.15 ounces of gold per ton equivalent over 106 feet. Drill hole LO-159 intersected three distinct massive sulfide horizons separated by zones of disseminated and stringer sulfide mineralization. The entire interval totaled 225.3 feet of 0.07 ounces of gold per ton, 2.74 ounces of silver per ton, 1.67 percent copper and 4.05 percent zinc. True width of the intersection is approximately 200 feet. High-grade subintervals include 46.3 feet of 0.13 ounces of gold per ton, 2.07 ounces of silver per ton, 3.05 percent copper, and 7.79 percent zinc, and 21.1 feet grading 0.05 ounces of gold per ton, 2.57 ounces of silver per ton, 4.03 percent copper and 13.28 percent zinc. A separate 79.5 -foot interval of mineralization was also intersected in LO-159, grading 0.07 ounces of gold per ton, 1.28 ounces of silver per ton, 1.25 percent copper, and 2.05 percent zinc. Drill hole LO-156 intersected 35.4 feet of 0.09 ounces of gold per ton, 2.31 ounces of silver per ton, 2.42 percent copper, and 3.16 percent zinc starting at 180 feet depth, and 4.2 feet of 0.05 ounces of gold per ton, 1.81 ounces of silver per ton, 11.3 percent copper, and 1.47 percent zinc starting at 724.1 feet depth.

At the Greens Creek underground mine near Juneau, Kennecott Minerals Co. drilled south and west of current workings and development drifting to explore additional reserves south of the 200 South, the West Bench, and the Deep Lower Southwest ore zones. Drilling into the West Gallagher Zone across the Gallagher fault from the current underground working areas at Greens Creek returned good results. In addition, the Gallagher Fault zone was successfully crossed with an underground exploration drift, and drill platforms were built to explore the new Gallagher zone. Surface exploration included diamond drilling on at least eight different prospects; geochemical soil sampling and geophysics along new gridlines in three prospects; and continued detailed geologic mapping and sampling of all active prospects.

Underground definition, pre-production, in-stope, mine-operation and exploration drilling at Greens Creek totaled more than 78,000 feet, with nearly 30,000 feet of that solely dedicated to new exploration. Results from drilling into the Gallagher zone were very encouraging. Many drill holes intercepted various amounts of white baritic, white carbonate, and massive sulfide lithologies similar to ore currently mined at Greens Creek. There are at least two mineralized zones dipping shallowly to the southwest. However, true thicknesses of mineralization are still unknown, and the zones are still open to the west and south. The most significant mineralized intercepts to date include 90 feet of continuous massive sulfide mineralization in one hole, with composite grades of 0.15 ounces of gold per ton, 4.8 ounces of silver per ton, 6.8 percent lead, and 20.5 percent zinc; and 108.8 feet of continuous massive sulfide, white carbonate and white baritic mineralization in another hole, with composite grades of 0.26 ounces of gold per ton, 3.2 ounces of silver per ton, 4.6 percent lead, and 11.5 percent zinc. Other significant intercepts include a third hole with 52 feet of massive sulfide and white carbonate mineralization, with composite grades of 0.2 ounces of gold per ton, 10.3 ounces of silver per ton, 5 percent lead, and 11.3 percent zinc; and 12.7 feet of massive sulfide mineralization and mineralized argillite in a fourth hole, with composite grades of 0.05 ounces of gold per ton, 41.7 ounces of silver per ton, 3.9 percent lead, and 7.6 percent zinc. The existing drift across the fault will be further advanced next year in order to set up more exploration drilling platforms, to further define this newly discovered deposit and possibly identify and quantify a resource by the end of 2006.

Coeur Alaska Inc. continued gold exploration on its Kensington property near Juneau with a \$2.2 million underground drilling program while mine development began in 2005. A total of 74 holes, totaling approximately 34,000 feet of core, were completed in 2005 and 87 percent of the holes encountered gold mineralization above the current cut-off grade of 0.12 ounces of gold per ton. Based on the drilling, Coeur expects to convert a significant portion of the existing mineralized resources into reserves. Coeur also conducted a \$0.7 million exploration-drilling program on the adjacent Jualin property and completed approximately 5,000 feet of core drilling.

Quaterra Resources Inc. completed seven diamond drill holes totaling 4,505 feet on coincident geochemical and geophysical anomalies in the Marquis, Potato Patch, and Raven zones on the Duke Island ultramafic-hosted copper-nickel-cobalt-platinum-group-element property near Ketchikan. Drilling targeted airborne and ground electromagnetic conductors in the eastern Marquis zone (holes DK0501 and DK0502) and intercepted wide intervals of 
anomalous copper mineralization, with the best interval returning 99.5 feet grading 0.23 percent copper with 140 parts per billion (ppb) combined platinum and palladium. This zone also contained anomalous cobalt (40 to 608 parts per million [ppm]) and nickel (102 to 2,730 ppm) that correlate well with elevated copper and platinum-groupelement values. Mineralization consisted of disseminated chalcopyrite and pyrrhotite hosted in variably serpentinized clinopyroxenite and olivine pyroxenite. Hole DK0503 in the Potato Patch zone intercepted 149 feet grading 0.21 percent copper in pyroxenite before passing into hornblende pyroxenite and diorite that contained significantly lower copper values. Hole DK0506 at the Raven zone contains the thickest interval of continuous copper mineralization drilled on the property to date, with the interval from 8 feet to 395 feet averaging 0.20 percent copper, $56 \mathrm{ppb}$ platinum and $59 \mathrm{ppb}$ palladium. The 42 foot interval from 33 feet to 75 feet averaged 0.38 percent copper and $644 \mathrm{ppb}$ platinum plus palladium. Structural and/or stratigraphic controls of mineralization are still poorly understood. At least 11 sulfide-bearing exploration targets occur within a 9-mile by 2.3-mile area, with the area open to expansion.

Bravo Venture Group Inc. conducted reconnaissance surface exploration of the "Blue Quartz" auriferous veins in the southwestern portion of Woewodski Island. Vein quartz, often with a distinctive blue color, is widely disbursed throughout the southern and western parts of the island as rare outcrops near shoreline and as float in linear drainages extending inland. High-grade quartz veins, some containing visible gold, were sampled in float and outcrop exposures for up to 1,600 feet along a north-northeast trend. Two trends of gold mineralization were identified and highgrade gold in narrow quartz veins was exposed in hand-dug trenches.

\section{DEVELOPMENT}

Reported and estimated mineral development expenditures in 2005 exceeded $\$ 347$ million, a 66 percent increase over the 2004 value of \$209.1 million. The increase is primarily due to construction at the Teck-Pogo project, which was fully permitted in mid 2004. Other significant investments took place at the Fort Knox Mine, the Greens Creek Mine, the Kensington project, the Red Dog Mine, and the Rock Creek project.

Construction at the Pogo gold project by Teck-Pogo Inc. was the major mining development in Alaska during 2005. Teck-Pogo is the project operator and a subsidiary of Teck Cominco Inc., which owns a 40 percent interest in the Pogo deposit. Co-owners are Sumitomo Metal Mining Co., which owns a 51 percent interest, and Sumitomo Corp., which holds 9 percent interest in the mine. Construction of the mine and associated facilities was mostly completed by January 2006, including a 50-mile $138 \mathrm{kV}$ power trans- mission line, permanent camp for 200 people, gold processing facilities, water treatment plant, and paste backfill plant/dry-stack tailings facility. A new 50-mile all-season road provides access to the site from the Richardson Highway north of Delta Junction to the property. The final project capital cost is estimated at $\$ 347$ million. Project costs increased due to higher-than-expected costs for construction materials and labor costs in Alaska, and unanticipated geotechnical conditions both on surface and underground. Commissioning of some of the process systems began and ore was placed on stockpile for the start-up. Underground development fell behind schedule and continued into 2006 due to poor ground conditions in some areas that caused a change of location of the underground ore bin and reduced the overall rate of advance. This schedule change affected only the start-up of the underground conveyor system, not the overall mine startup, as trucking of ore to the mill will be used as a stop-gap measure until the conveyor system is completed in the first quarter of 2006. On January 12, 2006, the first feed was introduced to the mill two months ahead of schedule. The first gold pour occurred on February 12, 2006.

The Pogo Mine has a reserve of 7.7 million tons of ore with a grade of slightly less than 0.47 ounces of gold per ton. Mining will be conducted by the "cut and fill” and "drift and fill" methods. The mill treatment rate will be 2,500 tons per day, with about half of the tailings returned to the mine for backfill; the remaining tailings will be dry stacked on the surface. Milling will incorporate grinding, gravity concentration, flotation, cyanide leaching of the concentrate, and tailings dewatering. Gold from both the gravity and carbon-in-pulp circuits is produced as doré bullion. Annual gold production is forecast to be 350,000500,000 ounces. Production from the Pogo mine in 2006 is projected at approximately 195,000 ounces.

Construction at Coeur Alaska Inc's Kensington underground gold mine complex in southeastern Alaska, 45 miles north of Juneau, began in mid year 2005, but NGO lawsuits against federal agencies delayed some phases of construction. Coeur Alaska received all the necessary permits to move forward with the Kensington gold mine project. The U.S. Army Corps of Engineers issued a permit allowing mine tailings to be placed in the Lower Slate Lake, a 23-acre alpine lake. The Federal District Court in Alaska granted a remand of the Section 404 permit to the Army Corps of Engineers and on November 22, 2005, the U.S. Army Corps of Engineers suspended the permit for further review. Coeur is currently conducting construction activities not governed by the Section 404 permit. The Kensington deposit has 1.0 million ounces of gold contained in 4.2 million tons of ore with a grade of 0.25 ounces of gold per ton. Coeur plans a production rate of 100,000 ounces per year at a cash operating cost of $\$ 250$ per ounce. The capital cost estimate is $\$ 190$ million. The milling pro- 
cess will involve treating approximately 1,150 tons of ore per day. The process will involve primary crushing, SAG mill grinding, gravity, and flotation concentration with about 40 percent of the tailings returned to the mine for backfill; the remaining tailings will be sent to the Lower Slate Lake tailings storage facility. Concentrates will be packaged and shipped off site for final gold recovery. The Kensington mine will employ about 300 workers during construction and provide an estimated payroll of up to $\$ 16$ million. When in operation, the mine will provide approximately 225 direct and 499 indirect jobs. The project is estimated to generate $\$ 4.1$ million in corporate income taxes and nearly \$2 million in mining licensing taxes in addition to generating local tax revenue.

Fairbanks Gold Mining, a subsidiary of Kinross Gold, continued advance stripping of ore during 2005 and acquired new mining equipment, including a Caterpillar 240-ton haul truck, two 200-ton haul trucks and a loader, to improve the daily haulage capacity at Fort Knox Mine near Fairbanks. Capital expenditures for 2005 by Kinross Gold at Fort Knox gold mine were approximately \$69.5 million and were mainly attributed to the Phase 6 capital development at the Fort Knox pit. In addition, the company began investigation and permitting of a valley-type heap leach of its lower grade materials. Knight Piésold and Company was the consulting firm for this project. The heap is designed to contain 160 million tons of low-grade ore. The proposed pad will cover 279 acres.

St. Andrew Goldfields Ltd. and its subsidiary, Mystery Creek Resources Inc., plan production in the third quarter of 2006 at the historic high-grade (average mined grade more than 1 ounce of gold per ton) Nixon Fork gold-copper mine in west-central Alaska. Roscoe Postle Associates Inc. finalized a resource estimate in April 2005 that included 2004 definition drilling. Only the C3000 and C3300 zones were drilled sufficiently enough to have measured resources of 8,816 tons at 1.09 ounces of gold per ton and 16,971 tons at 1.06 ounces of gold per ton, respectively. The measured resource at Nixon Fork is 27,700 ounces of gold, using an economic cut-off of 0.61 ounces of gold per ton. Indicated resources at Nixon Fork total 74,956 tons at an average grade of 0.968 ounces of gold per ton. The indicated resources are 72,600 ounces of gold. Most of the indicated resources are in the Mystery, C-3000, and C3300 zones, with smaller resources in the S-1750, J-2102, C-30001, C-30002, and C-3550 zones. Inferred resources total 38,570 tons grading 0.81 ounces of gold per ton from the J-2102, C-330, C-3550, and Whalen zones. The tailings contain an additional inferred resource of 127,832 tons grading 0.236 ounces of gold per ton, or 30,168 ounces of gold. The total measured, indicated, and inferred gold resource is 161,700 ounces. Drilling in the C-3000 and C-3300 ore chutes at the Crystal Mine area at Nixon Fork has been completed on 23-foot centers. Because of the small and complex nature of the skarns and the mining methods proposed at Nixon Fork, some of the sub-economic gold mineralized material, not considered in the Roscoe Postle study, could be included in the stope plans as internal dilution.

The Alaska Department of Environmental Conservation issued an Air Quality Control Construction Permit on July 7, 2005. The Alaska Department of Natural Resources issued a Certificate of Approval to Operate Dam on August 31, 2005. In late October 2005 the Nixon Fork Plan of Operations, Environmental Assessment, and draft Solid Waste Disposal Permits, the key permits required for commercial production, were posted for public comment. Regulators are currently evaluating the comments received, resolving issues, and finalizing the permit documents. Mystery Creek is currently in the process of reconditioning and modifying the existing milling facilities, purchasing new equipment to allow cyanide treatment of both existing and new tailings and beginning new mine development at the site in anticipation of new production beginning in the third quarter of 2006.

NovaGold Resources Inc.'s Rock Creek gold project on the Seward Peninsula is likely to undergo construction in 2006, with first production projected for early 2007. NovaGold completed additional in-fill drilling and metallurgical test work as part of the final feasibility study. The feasibility study was completed by the independent engineering firm Norwest Corp. In addition, project permitting progressed on schedule and permits necessary to start construction are anticipated to be in place by mid 2006. A mine construction decision at Rock Creek will be made after receipt of construction permits. NovaGold purchased certain equipment with long lead times to ensure delivery into Nome by the summer of 2006 to begin construction of the mine. The Rock Creek project is anticipated to produce an average of 100,000 ounces of gold per year at a total cash cost of around $\$ 250$ per ounce. The company envisions the development of the Rock Creek deposit as part of an integrated operation that includes Rock Creek, Saddle and Big Hurrah deposits, and the Nome Gold alluvial deposits that collectively contain in excess of 3 million ounces of gold resource.

PacRim Coal LP announced initiation of permitting for the Chuitna Coal project, located west of Anchorage on the north side of Cook Inlet. Previous work outlined 300 million tons of recoverable subbituminous coal with low sulfur content. During 2005 PacRim updated baseline environmental studies and engineering studies. The project is designed as a coal export terminal with 3 to 12 million tons per day capacity and a 12-mile-long covered conveyor from mine facilities. Construction for this project is scheduled for 2007 with production in 2009. Construction costs will be approximately $\$ 650$ million. 


\section{PRODUCTION}

A preliminary estimate of mineral production value in Alaska during 2005 was \$1,357 million. Significant reporting shortfalls are noted in the placer and industrial minerals sectors; when final totals are determined, the numbers are expected to increase significantly. Metals (gold, silver, lead, and zinc) account for \$1,251.2 million, coal and peat for $\$ 49.8$ million, and industrial minerals for $\$ 56.3$ million. The estimate represents an increase in value of nearly \$18 million over the 2004 production value, even though production volumes were down in all metal sectors. Table 4 shows the estimated mineral production for 2003 through 2005. Significant production sites are shown in figure 4.

The Red Dog Mine near Kotzebue in northwestern Alaska is the world's largest zinc producer and it dominated Alaska's mineral production value. Red Dog Mine accounted for well over 50 percent of the annual value of Alaska's mineral industry. The Red Dog mine is 100 percent owned and operated by Teck Cominco Alaska Inc. under an agreement with NANA Regional Corp., a Native
Alaskan development corporation. The Red Dog deposit comprises a number of sedimentary-hosted exhalative (SEDEX) lead-zinc sulfide deposits hosted in Mississippian-age to Pennsylvanian-age sedimentary rocks. The ore bodies are lens shaped and occur within structurally controlled (thrust fault) plates. The sulfide mineralization consists of semi-massive to massive sphalerite, pyrite, marcasite, and galena. The mining method employed is conventional drill and blast open-pit mining. The main pit has an expected life of 7 years at current rates of production. Additional reserves have been identified in the vicinity of the processing facilities sufficient to extend the life of the operation by 16 more years for a total mine life of 23 years. The mineral processing facilities employ conventional grinding and sulfide flotation methods to produce zinc and lead concentrates. The shipping season at Red Dog is restricted to approximately 100 days per year because of sea ice conditions and Red Dog's sales are seasonal with the majority of sales in the last five months of each year. Concentrate is stockpiled at the port facility and is typically shipped between July and October.

Table 4. Estimated mineral production in Alaska, 2003-2005a

\begin{tabular}{|c|c|c|c|c|c|c|}
\hline \multirow[b]{2}{*}{ Metals } & \multicolumn{3}{|c|}{ Quantity } & \multicolumn{3}{|c|}{ Estimated Values $^{\mathbf{b}}$} \\
\hline & 2003 & 2004 & 2005 & 2003 & 2004 & 2005 \\
\hline Gold (ounces) ${ }^{\mathrm{C}}$ & 528,191 & 456,508 & 423,289 & $191,934,000$ & $192,934,000$ & $188,253,000$ \\
\hline Silver (ounces) & $18,589,100$ & $16,947,270$ & $11,700,000$ & $95,300,000$ & $113,056,930$ & $85,602,000$ \\
\hline Copper (tons) ${ }^{\mathrm{d}}$ & $0^{\mathrm{d}}$ & $0^{\mathrm{d}}$ & $0^{\mathrm{d}}$ & 0 & 0 & 0 \\
\hline Lead (tons) & 162,479 & 150,796 & 131,366 & $64,279,000$ & $120,636,822$ & $115,230,000$ \\
\hline Zinc (tons) & 714,769 & 680,015 & 684,462 & $536,348,000$ & $651,432,200$ & $862,108,000$ \\
\hline Subtotal & & & & $\$ 887,861,000$ & $\$ 1,078,059,952$ & $\$ 1,251,193,000$ \\
\hline \multicolumn{7}{|l|}{ Industrial Minerals } \\
\hline Jade and soapstone (tons) & $0.0^{\mathrm{e}}$ & 0.0 & 0.0 & 0 & 0 & 0 \\
\hline Sand and gravel (million ton & 11.9 & $19.6^{f}$ & 6.6 & $64,140,000$ & $101,507,347$ & $35,701,000$ \\
\hline Rock (million tons) & 0.9 & $7.3^{f}$ & 2.6 & $10,406,000$ & $106,207,814$ & $20,618,000$ \\
\hline Subtotal & & & & $\$ 74,546,000$ & $\$ 207,715,161$ & $\$ 56,319,000$ \\
\hline Coal (tons) & $1,088,000$ & $1,450,000$ & $1,402,174$ & $38,080,000$ & $50,750,000$ & $49,076,000$ \\
\hline Peat (cubic yards) & $35,000^{g}$ & 208,032 & 60,032 & 175,000 & $2,732,554$ & 769,000 \\
\hline Subtotal & & & & $\$ 38,255,000$ & $\$ 53,482,554$ & $\$ 49,845,000$ \\
\hline TOTAL & & & & $\$ 1,000,662,000$ & $\$ 1,339,257,667$ & $\$ 1,357,357,000$ \\
\hline
\end{tabular}

aProduction data from DGGS questionnaire, phone interviews with mine and quarry operators, ADOT\&PF, and municipalities, Regional Corp., and federal land management agencies.

${ }^{b}$ Values for selected metal production was based on average prices for each year; (unless other values were provided by the operator); for 2005 , gold $\$ 444.74$, silver $\$ 7.32 / \mathrm{oz}$, lead $\$ 0.43 / \mathrm{lb}$, zinc $\$ 0.63 / \mathrm{lb}$, coal $\$ 25.53 /$ ton, rounded to nearest $\$ 1,000$.

cHardrock gold - 402,120 ounces, placer gold - 21,169 ounces.

${ }^{\mathrm{d}}$ Greens Creek has historically been credited with a small copper concentrate production; no credit was experienced for 2003, 2004, and 2005.

eJade and soapstone credit has been dropped.

${ }^{f}$ Low values reflect incomplete information at this time.

gProjected only; no reports from producers. 
Figure 4. Selected significant production sites in Alaska, 2005.

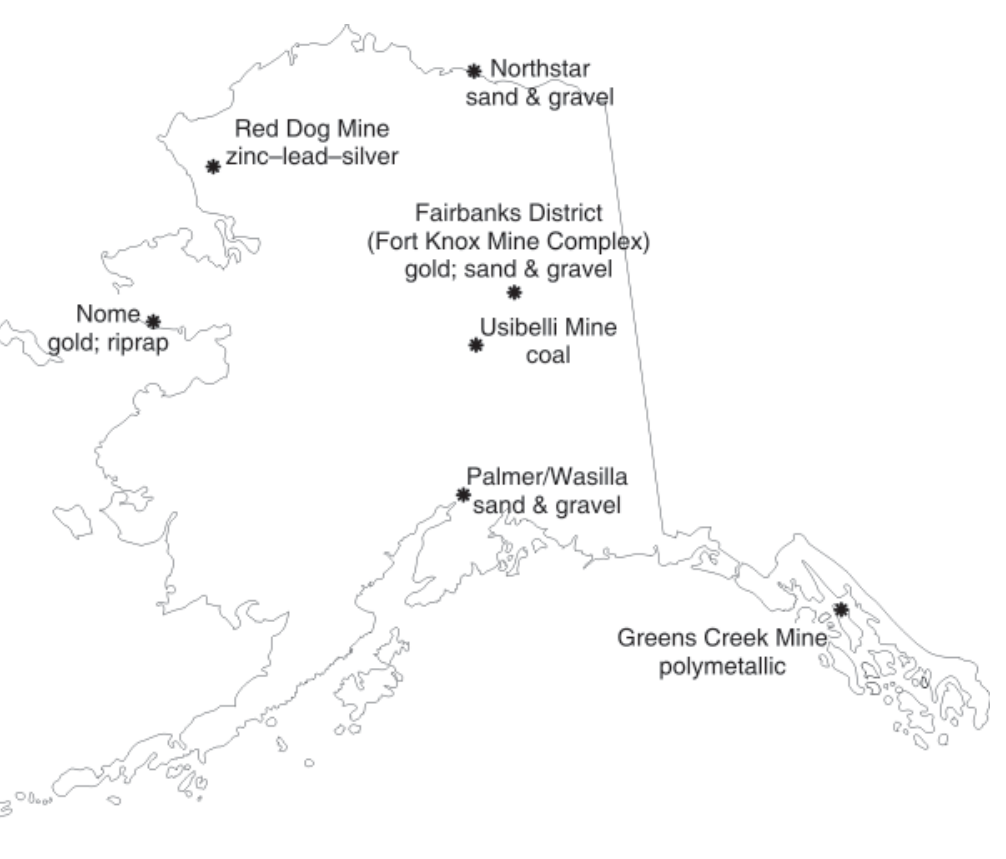

Teck reported an operating profit at the Red Dog Mine of \$268 million in 2005. The mine milled 3.4 million tons of ore with a zinc grade of 21.70 percent and a lead grade of 5.60 percent. The Red Dog Mine produced 625,936 tons of zinc, 112,734 tons of lead, and an estimated 2 million ounces of silver in 2005. Silver production is down from previous years as a result of a different method of calculating its production - only that credited to the operation after smelting and refining fees. The shipping season was completed on October 21, 2005, with a total of 1.1 million tons of zinc concentrate and 220,000 tons of lead concentrate shipped from the mine. A shallow gas exploration program returned positive preliminary results, and a follow-up program is planned for 2006 to determine the economic potential of natural gas as a replacement for diesel fuel used for power generation.

Greens Creek Mine, a Kennecott Minerals Co.-Hecla Mining Co. joint venture in southeastern Alaska, is a polymetallic volcanogenic massive sulfide deposit (silver, zinc, gold, lead, and copper) and one of the largest silver producers in the world. It produces a silver-gold doré and sulfide concentrates containing zinc, lead, and minor copper; copper is no longer reported.

Production at Greens Creek Mine dropped slightly from the record levels of 2004. Metal production totaled 9.7 million ounces of silver, 72,800 ounces of gold, 58,350 tons of zinc, and 18,600 tons of lead. Reserves at the end of 2005 are 7.5 million tons of ore grading 14.36 ounces of silver per ton, 0.116 ounces of gold per ton, 10.24 percent zinc, and 3.89 percent lead.

Fairbanks Gold Mining Co. Inc., a subsidiary of Kinross Gold Inc., operated the open-pit Fort Knox Mine near
Fairbanks. Gold production decreased by 2.7 percent compared to 2004 due to lower grade and less mill throughput, which was partially offset by a higher recovery. The lower grade in 2005 was the result of the suspension of production at the True North deposit in 2004. The lower mill throughput was the result of processing harder Fort Knox ore compared with blended ore from True North and Fort Knox for much of the prior year. Fairbanks Gold mined 13.23 million tons of ore and 5.86 million tons of lowgrade ore to stockpile. The waste stripping volume was 44.16 million tons. Mill throughput amounted to 14.38 million tons at a calculated grade of 0.0229 ounces of gold per ton. The Fort Knox mill averaged 39,400 tons per day feed rate during 2005. Production for 2006 is forecast to be lower than 2005, with improved recovery rates expected to be offset by lower grades.

During 2005, Kinross conducted a comprehensive review of its assets and investments. The True North and Gil deposits were reclassified from reserves to resources and Kinross elected to withdraw from the Ryan Lode project.

Fairbanks Gold continued working on the Phase 6 layback of the Fort Knox open-pit gold mine approved in April 2004. Crews have been working to move 75 million tons of waste rock since mid 2004, with the schedule calling for accessing the gold-bearing rock in late 2006. The estimated 1 million ounces of gold accessible by the Phase 6 layback will be mined through 2010, with plans to process stockpiles and operate the heap leach for several years after that.

Usibelli Coal Mine produced subbituminous coal from its Two Bull Ridge pit near Healy, with an output of 1.4 million tons of coal, a slight decrease of 50,000 tons from 
the 2004 production. Korean shipments continued, with 399,833 tons sent to that destination via the Alaska Railroad to the Seward Coal Terminal and by ship from that point. Test shipments continued to Chile, totaling 102,925 tons of coal in 2005. The mine also supplies six power plants in interior Alaska with approximately 900,000 tons annually.

Mining crews at Silverado Gold Mines Ltd.'s Nolan Gold project, 280 road miles north of Fairbanks in the Brooks Range, installed a new portal and extended the underground workings into the Swede Channel to access additional underground placer gold resources. A short drilling program before the mining operations defined the extent of planned excavation. The ore material was brought to surface and will be processed in 2006 after surface waters are thawed. Silverado stockpiled a few thousand cubic yards of gravel during the winter, with operations completed in March 2006. Sluicing of the stockpiled gravel will begin during June 2006, and be completed by the end of July 2006.

Placer gold, rock, sand, and gravel production numbers for 2005 were down considerably from 2004. The decrease is thought to be due to a serious shortfall in reporting, rather than an actual production deficit. Efforts are ongoing to elicit reports.

\section{DRILLING}

Tables 5 and 6 summarize the drilling activity in the state during 2005 by region and type of drilling. Drilling was conducted during all phases of mining (exploration, development, and production) on various projects across Alaska during 2005. Preliminary drilling totals for 2005 are 595,670 feet of core drilling, 40,220 feet of reversecirculation drilling, and 3,360 feet of placer auger/churn drilling. There was no drilling reported for coal operations. The drilling results are considered incomplete at this time.

Major drill programs were conducted in most areas of the State. The largest drilling programs were in southwestern Alaska, with drilling by Placer Dome Inc. on the Donlin Creek property, by Northern Dynasty Minerals Ltd. at the Pebble property, and by Liberty Star Gold Corp. on the Big Chunk property. In southeastern Alaska, Kennecott Minerals Co. had the largest program, including development definition drilling and surface and underground exploration drilling at Greens Creek Mine. Other drilling programs in southeastern Alaska were conducted by Coeur Alaska Inc. at the Kensington and Jualin properties, by Freegold Ventures Ltd./Pacific North West Capital Corp./ Lonmin PLC at the Union Bay property, by Niblack Mining Corp. on the Niblack property, and by Quaterra Resources Inc. at the Duke Island property. A major drilling program was conducted in the eastern Interior region by Kinross Gold Corp. (Fairbanks Gold Mining Inc.) in the Fairbanks mining district including Fort Knox Mine. In southcentral Alaska, major drilling programs were conducted by Kennecott Exploration Co. at the Whistler property, by Piper Capital Inc. on the Golden Zone property, and by Anglo American on the MAN property. AngloGold Ashanti (USA) Exploration Inc. drilled at several properties including the LMS and Terra projects. NovaGold Resources Inc. drilled at the Rock Creek, Big Hurrah, Khotol, and Arctic properties in the northern and western regions. Teck Cominco Alaska Inc. drilled in the Red Dog area and on the Pogo property, and St. Andrew Goldfields Ltd./Mystery Creek Resources Inc. continued underground drilling at the Nixon Fork property.

Table 5. Drilling footage by region in Alaska, 2005

\begin{tabular}{|c|c|c|c|c|c|c|c|}
\hline Type of drilling & Northern & Western & $\begin{array}{l}\text { Eastern } \\
\text { Interior }\end{array}$ & $\begin{array}{l}\text { South- } \\
\text { central }\end{array}$ & $\begin{array}{l}\text { South- } \\
\text { western }\end{array}$ & $\begin{array}{l}\text { South- } \\
\text { eastern }\end{array}$ & TOTAL \\
\hline Placer subtotal & - & 60 & 3,300 & - & - & - & 3,360 \\
\hline Coal subtotal & - & - & - & - & - & - & 0 \\
\hline Hardrock core & 15,762 & 79,951 & 87,075 & 74,932 & 158,430 & 179,520 & 595,670 \\
\hline Hardrock rotary & 0 & 0 & 25,000 & 200 & 15,020 & 0 & 40,220 \\
\hline Hardrock subtotal & 15,762 & 79,951 & 112,075 & 75,132 & 173,450 & 179,520 & 635,890 \\
\hline TOTAL (feet) & 15,762 & 80,011 & 115,375 & 75,132 & 173,450 & 179,520 & 639,250 \\
\hline
\end{tabular}


Table 6. Drilling footage reported in Alaska, 1982-2005

\begin{tabular}{|c|c|c|c|c|c|c|c|c|}
\hline Year & $\begin{array}{c}\text { Placer } \\
\text { Exploration }\end{array}$ & $\begin{array}{c}\text { Placer } \\
\text { Thawing }\end{array}$ & $\begin{array}{c}\text { TOTAL } \\
\text { PLACER }\end{array}$ & $\begin{array}{c}\text { TOTAL } \\
\text { COAL }\end{array}$ & $\begin{array}{c}\text { TOTAL } \\
\text { HARDROCK }\end{array}$ & $\begin{array}{c}\text { Hardrock } \\
\text { Core }^{\mathrm{a}}\end{array}$ & $\begin{array}{c}\text { Hardrock } \\
\text { Rotary }^{\mathbf{a}}\end{array}$ & $\begin{array}{c}\text { TOTAL } \\
\text { FEET }\end{array}$ \\
\hline 1982 & 30,000 & 94,000 & 124,000 & 80,000 & 200,000 & - & - - & 404,000 \\
\hline 1983 & 23,000 & 30,000 & 53,000 & 12,000 & 180,500 & - & - & 245,500 \\
\hline 1984 & 31,000 & 98,000 & 129,000 & 25,700 & 176,000 & - - & - - & 330,700 \\
\hline 1985 & 46,000 & 34,000 & 80,000 & 8,700 & 131,700 & - - & - - & 220,400 \\
\hline 1986 & 32,400 & 227,000 & 259,400 & $\mathbf{2 8 , 8 0 0}$ & 50,200 & - - & - - & 338,400 \\
\hline 1987 & 50,250 & 130,000 & 180,250 & 19,900 & 115,100 & 95,600 & 19,500 & 315,250 \\
\hline 1988 & 152,000 & 300,000 & 452,000 & 26,150 & 353,860 & 223,630 & 130,230 & 832,010 \\
\hline 1989 & 97,250 & 210,000 & 307,250 & 38,670 & 332,230 & 242,440 & 89,790 & 678,150 \\
\hline 1990 & 78,930 & 105,000 & 183,930 & 18,195 & 760,955 & 648,600 & 112,355 & 963,080 \\
\hline 1991 & 51,247 & 130,000 & 181,247 & 16,894 & 316,655 & 205,805 & 110,850 & 514,796 \\
\hline 1992 & 6,740 & 65,000 & 71,740 & 12,875 & 359,834 & 211,812 & 148,022 & 444,449 \\
\hline 1993 & 25,216 & - - & 25,216 & - - & 252,315 & 124,325 & 127,990 & 277,531 \\
\hline 1994 & 21,000 & - - & 21,000 & 8,168 & 438,710 & 347,018 & 91,692 & 467,878 \\
\hline 1995 & 27,570 & - & 27,570 & - - & 415,485 & 363,690 & 51,795 & 443,055 \\
\hline 1996 & 61,780 & -- & 61,780 & 8,500 & 658,857 & 524,330 & 134,527 & 729,137 \\
\hline 1997 & 38,980 & - - & 38,980 & 13,998 & 704,510 & 523,676 & 180,834 & 757,488 \\
\hline 1998 & 33,250 & - & 33,250 & 2,300 & 551,078 & 505,408 & 45,670 & 586,628 \\
\hline 1999 & 6,727 & - - & 6,727 & - - & 448,797 & 369,863 & 78,934 & 455,524 \\
\hline 2000 & 15,480 & - - & 15,480 & - - & 546,268 & 418,630 & 127,638 & 561,748 \\
\hline 2001 & 1,100 & - - & 1,100 & 36,151 & 316,068 & 240,318 & 75,750 & 353,319 \\
\hline 2002 & 1,250 & - & 1,250 & - - & 488,902 & 385,290 & 103,612 & 490,152 \\
\hline 2003 & 10,108 & - & 10,108 & 2,000 & 370,634 & 270,456 & 100,178 & 382,742 \\
\hline 2004 & 107,526 & - & 107,526 & - - & 451,652 & 415,628 & 36,024 & 559,178 \\
\hline 2005 & 3,360 & - & 3,360 & - & 635,890 & 595,670 & 40,220 & 639,250 \\
\hline
\end{tabular}

\section{GOVERNMENT ACTIONS}

Geologists from the Minerals Resources Section of the Alaska Division of Geological \& Geophysical Surveys (DGGS) mapped and sampled 131 square miles around the historic Liberty Bell Mine near Healy. Geochemical data from this work was released in November. A 1:50,000scale geologic map will be available in mid 2006.

DGGS released a series of new 1:50,000-scale surficial and bedrock geologic maps of the Council and Big Hurrah areas of the southern Seward Peninsula as part of an integrated program following up the airborne geophysical survey results previously released by DGGS in 2003 and fieldwork conducted in 2004.

DGGS released new trace-element geochemical data from reanalysis of archived stream-sediment pulps originally collected in 1982 near the town of Livengood. DGGS found 952 of the 1,597 stream-sediment samples collected in 1982 and AngloGold Ashanti North America Inc. paid for the new geochemical analyses. This data complements data collected over 130 square miles of the central Livengood Quadrangle in 2001 and 2003.
DGGS released a 220-square-mile airborne magnetic and electromagnetic geophysical survey in the southern Goodpaster region of the Big Delta Quadrangle in early 2005. DGGS funded and acquired airborne magnetic and electromagnetic geophysical surveys for 944 square miles of highly prospective areas for mineral deposits in the Fairbanks, Circle, Richardson, and Goodpaster mining districts. The survey maps and data were released in 2006. Geophysical surveys funded by the U.S. Bureau of Land Management for 1,450 square miles of mineral-rich lands in the southern National Petroleum Reserve-Alaska were flown in 2005 and released by DGGS in early 2006. These data, all historic DGGS publications, and most U.S. Geological Survey publications about Alaska's geology and resources are available for download at no charge at the DGGS Web site (http://www.dggs.dnr.state.ak.us).

To date, with an investment of $\$ 6$ million, in excess of 6.1 million acres (more than 9,500 square miles) of Alaska were flown for detailed geophysical surveys and about 2.7 million acres of 1:63,360-scale geologic maps were produced as part of the State-funded Alaska Airborne Geophysical/Geological Mineral Inventory (AGGMI) Pro- 
gram. Federal monies through the STATEMAP Program fund some of the geologic mapping within the AGGMI Program.

The national U.S. Bureau of Land Management (BLM) Sustainable Mineral Development Reclamation Award was presented to Jim Olmstead, a miner on Gold Creek along the Dalton Highway. Forrest Hayden, Al Hopen, and the American Reclamation Group LLC were awarded the 2005 annual state reclamation awards by the Alaska Department of Natural Resources (DNR). Forrest Hayden placer mined on Squaw Creek in the Fortymile mining district, $\mathrm{Al}$ Hopen placer mined on Cleary Creek in the Fairbanks mining district and the American Reclamation Group mined the Illinois Creek Mine in the Kaiyuh mining district. American Reclamation Group reclaimed the bankrupt Illinois Creek gold-silver mine, a State-owned facility after the bankruptcy, by successfully heap-leaching the remaining ore and then reclaimed the heap leach and mine site to closure standards without use of State funds, All mine buildings were also removed from the site and mining equipment sold to other mine operators in the state.

Governor Murkowski appointed Mike Menge as the new Acting DNR Commissioner in November. Other appointments include Ed Fogels as acting deputy commissioner for all department operations other than oil, gas, and pipeline issues, Kenneth Griffin as acting deputy commissioner responsible for oil and gas issues, Robert Swenson as acting director of DGGS, Dick Mylius as acting director of the Division of Mining, Land, \& Water, Tom Crafford as acting project manager for the Large Mine Permitting Project, and Rick Fredericksen as acting manager for the Mining Resources Section. 


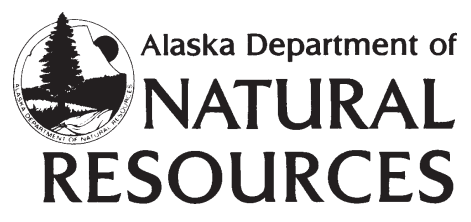

DEPARTMENT OF NATURAL RESOURCES

Division of Geological \& Geophysical Surveys http://www.dggs.dnr.state.ak.us

\section{DEPARTMENT OF COMMERCE, COMMUNITY \& ECONOMIC DEVELOPMENT Office of Economic Development \\ http://www.commerce.state.ak.us/oed/minerals/mining.htm}

